\title{
Mortuary Landscapes Revisited: Dynamics of Insularity and Connectivity in Mortuary Ritual, Feasting, and Commemoration in Late Bronze Age Cyprus
}

Teresa Bürge ${ }^{1,2}$ (D)

1 Department of Historical Studies, University of Gothenburg, 41255 Göteborg, Sweden; teresa.buerge@oeaw.ac.at

2 Austrian Archaeological Institute, Austrian Academy of Sciences, 1020 Vienna, Austria

\section{check for}

updates

Citation: Bürge, Teresa. 2021. Mortuary Landscapes Revisited: Dynamics of Insularity and Connectivity in Mortuary Ritual, Feasting, and Commemoration in Late Bronze Age Cyprus. Religions 12 877. https://doi.org/10.3390/ rel12100877

\section{Academic Editors:}

Giorgos Papantoniou, Athanasios K. Vionis and Christine E. Morris

Received: 1 September 2021

Accepted: 2 October 2021

Published: 14 October 2021

Publisher's Note: MDPI stays neutral with regard to jurisdictional claims in published maps and institutional affiliations.

Copyright: (C) 2021 by the author. Licensee MDPI, Basel, Switzerland. This article is an open access article distributed under the terms and conditions of the Creative Commons Attribution (CC BY) license (https:/ / creativecommons.org/licenses/by/ $4.0 /)$.

\begin{abstract}
The aim of the paper is to discuss mortuary contexts and possible related ritual features as parts of sacred landscapes in Late Bronze Age Cyprus. Since the island was an important node in the Eastern Mediterranean economic network, it will be explored whether and how connectivity and insularity may be reflected in ritual and mortuary practices. The article concentrates on the extraurban cemetery of Area A at the harbour city of Hala Sultan Tekke, where numerous pits and other shafts with peculiar deposits of complete and broken objects as well as faunal remains have been found. These will be evaluated and set in relation to the contexts of the nearby tombs to reconstruct ritual activities in connection with funerals and possible rituals of commemoration or ancestral rites. The evidence from Hala Sultan Tekke and other selected Late Cypriot sites demonstrates that these practices were highly dynamic in integrating and adopting external objects, symbols, and concepts, while, nevertheless, definite island-specific characteristics remain visible.
\end{abstract}

Keywords: Cyprus; Late Bronze Age; insularity; connectivity; ritual; commemoration; burials; mortuary practice; sacred space

\section{Introduction}

While the surrounding cultures of Mycenaean Greece, Crete, Anatolia, the Levant, and Egypt have yielded a wide variety of cultic remains, as well as iconographical and textual information on ritual and religion, the evidence from Late Bronze Age Cyprus (ca. 1650-1050 BCE) is sketchier. This is partly due to the lack of decipherable written sources from the island and partly dependent on the diversity reflected in the archaeological record. In fact, compared to the numerous well-known urban centres, the architectural evidence for built sanctuaries is somewhat elusive: it includes the cultic complexes at Athienou and Myrtou Pigadhes, as well as the monumental structures at Kition, Palaepaphos, and Enkomi (see a summary in Webb 1999, pp. 21-113), which are dated to the later part of the Bronze Age, i.e., the 13th and 12th centuries BCE. In addition, there are numerous important urban centres where clear cultic structures have not come to light-first and foremost at Hala Sultan Tekke. Hence, it is necessary to look at additional evidence of possible ritual and/or religious activities, some of which may have been overlooked in past research.

In contrast, the evidence of mortuary contexts is rich, albeit restrained by missing or limited research agendas, hasty and careless excavation, insufficient documentation, and the fact that many incomplete artefacts, as well as biofacts and human remains, were only rarely kept in the course of the extensive excavations on the island at the end of the 19th and the first half of the 20th century CE (Keswani 2004, pp. 24-26). Only in recent years, and especially owing to Priscilla S. Keswani's (2004) seminal study of mortuary ritual in Bronze Age Cyprus, it has become clear that this practice is highly complex, multi-faceted, and different from that of other Eastern Mediterranean regions, although foreign objects and other elements were frequently incorporated into burial contexts in the Late Bronze 
Age. Due to the lack of additional data, mainly burial contexts per se were discussed, while evidence of activities related to burials, but taking place outside tombs, such as feasting, commemoration, votive practices, and deposition were often neglected (cf. Webb 1992; Steel 2004; Keswani 2004, 2012a; Webb and Frankel 2008; Webb 2019 for the Early and Middle Cypriot periods).

Therefore, the aim of the paper is to discuss mortuary contexts and possible related ritual features as parts of sacred landscapes in Late Bronze Age Cyprus. A specific focus will be given to the question of whether and how specific objects and practices may have been integrated into local customs in the light of the island's highly multi-cultural and inter-connected character in this period. The movement of people, knowledge, ideas, and perceptions was one of the main driving forces of increased social and economic complexity (e.g., Knapp 1986) - but in what way is this reflected in the ritual sphere? What significance did insularity and connectivity have in relation to the mortuary landscape? The starting point of the study is the peculiar combination of tombs, wells, and ritual pits at Hala Sultan Tekke Area A (Bürge 2017). It will be extended to other areas of the same site as well as to other regions in selected case studies from Palaepaphos in the south-west, Toumba tou Skourou and Ayia Irini Paleokastro in the north, and Enkomi in the south-east (Figure 1).

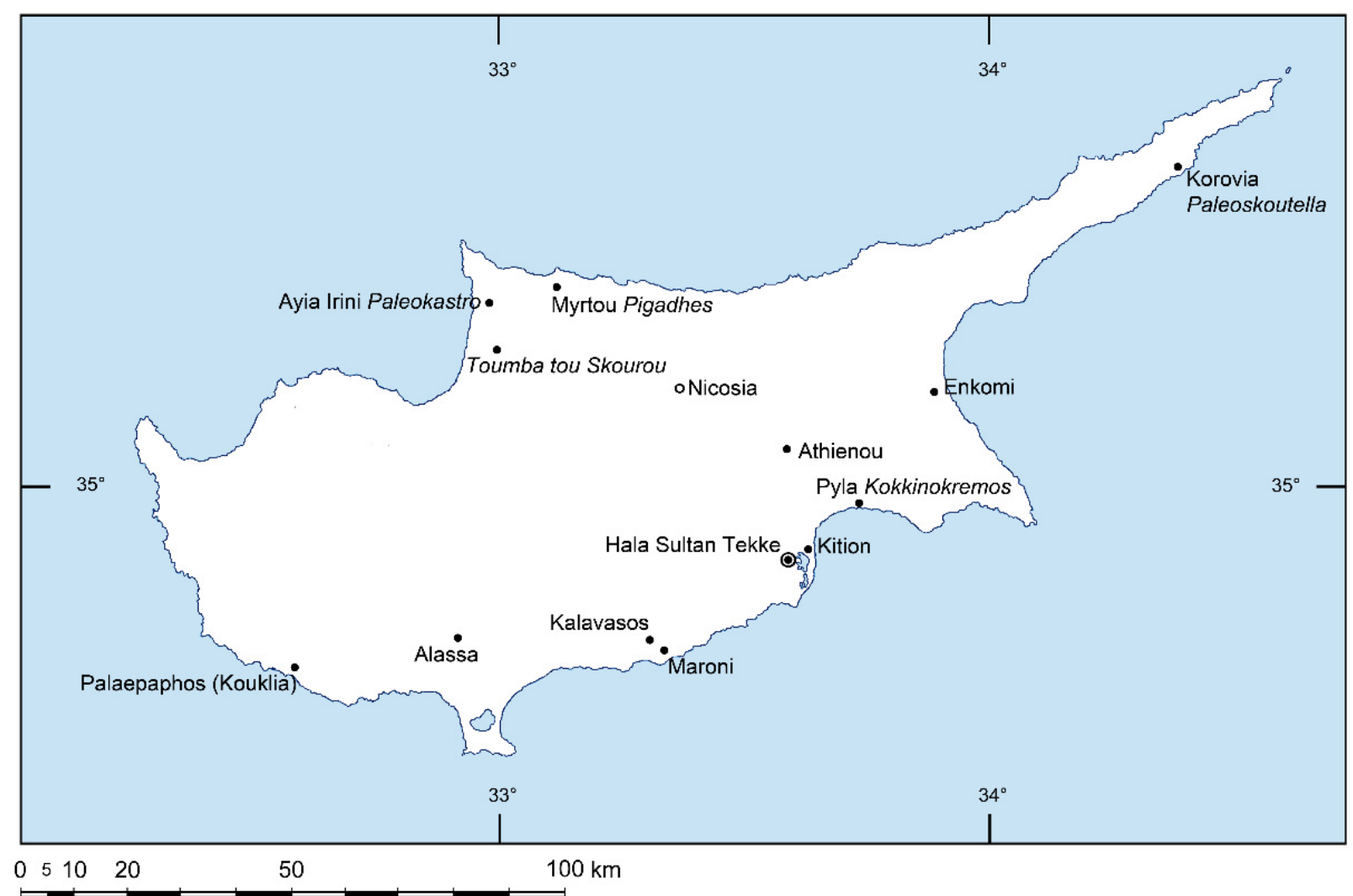

Figure 1. Map of Cyprus indicating Late Bronze Age sites mentioned in the text (drawing by the author).

\section{Insularity and Connectivity in Late Cypriot Religious and Ritual Spheres}

Late Bronze Age Cyprus, which has been often described as a melting pot and crossroads of civilisations of the eastern Mediterranean (and beyond), certainly was influenced by surrounding cultures as regards almost all aspects of society, including rituals, beliefs, and religion in general. The sea, as the most efficient form of mobility (Gordon and Kouremenos 2020) was more a bridge than a barrier and greatly facilitated the exchange of goods and ideas, as well as human mobility, which are the main criteria for connectivity as defined by Horden and Purcell (2000, pp. 123-72). The sailing routes in the Eastern Mediterranean inevitably passed Cyprus (e.g., Bar-Yosef Mayer et al. 2015; Safadi 2016; Safadi and Sturt 
2019) and the sought-after Cypriot copper stimulated trade and contacts from Cyprus to the surrounding regions.

Compared to other Mediterranean islands, Cyprus is very close to the nearest mainland, i.e., Anatolia and the Northern Levant, the mountains of which are, on clear days, visible from the Cypriot coast and vice versa (see also Horden and Purcell 2000, pp. 124-32; Bar-Yosef Mayer et al. 2015, p. 420). Depending on wind direction and weather conditions, waves and currents, season, and time of day, the surrounding coasts could be reached within only a few days (Broodbank 2000, pp. 345-47; Bar-Yosef Mayer et al. 2015; Safadi 2016; Safadi and Sturt 2019; Knapp 2020). Although mostly concerned with the Neolithic period, Bar-Yosef Mayer et al. (2015) calculate voyages of less than a day from Anatolia (Cape Anamur) to Cyprus (Cape Kormakitis/Morphou Bay) —while the way back may lead along the Northern Levantine coast and will therefore take longer-around a day from the Northern Levant (Latakia) to Cyprus, and one to two days from Cyprus to the Levantine coast (Beirut) under the most favourable conditions.

In fact, much has been written about the interconnected Late Bronze Age societies in the Eastern Mediterranean, the correspondence and diplomatic relations between different political powers, and the circulation of goods and élite items (see, e.g., contributions in Duistermaat and Regulski 2011; Aruz et al. 2013; Eder and Pruzsinszky 2015). Meanwhile, it seems more difficult to tackle if and in what way aspects of daily life or ritual and cult were affected by this 'globalisation' (see though, e.g., Eriksson 2008). We may imagine that Cyprus at this time was a cosmopolitan and polyglot society, which is, inter alia, epitomised in a silver bowl from Hala Sultan Tekke with an Ugaritic inscription most likely mentioning the owner with a Hurrian name and West-Semitic patronym (Åström and Masson 1982; Stieglitz 1984), although we do not know whether the bowl was produced and inscribed on Cyprus or at another place, such as Ugarit.

Taking a closer look at the material culture, Mycenaean imported fineware, mostly produced in the Argolid (Sterba), occurs in most conspicuous quantities not only in ritual, burial, and élite contexts but also in domestic areas (see summary in van Wijngaarden 2002, pp. 183-91). In addition, Levantine, Egyptian, and, to a lesser degree, also Anatolian imports and influences are ubiquitous (Fischer and Bürge 2017; Bürge and Fischer 2018). Despite the inter-connected character of the island and the incorporation of diverse material culture elements, it would be fallacious to assume that Late Cypriot ritual practice can be reconstructed analogous to that of the Aegean or the Levant, from where we have more substantial evidence. As we will see below, the issue of religion and ritual in relation to insularity and connectivity is highly complex: it is often associated with notions of tradition and conservatism, and seen in static terms (Knapp and Dommelen 2014, pp. 605-6). In particular preparation and consumption of food and drink, not only in rituals, is regarded as 'deeply embedded in cultural traditions' (Steel 2010, p. 109) and changes in these practices, which may be reflected in the material culture, are significant as being indicative of social transformations. On the other hand, rituals may also be a powerful source for transformation (Kelly and Kaplan 1990, pp. 139-40).

The selection of material remains that might express identity and insularity in the archaeological record needs to be carefully considered (see also Knapp 2007, p. 41) and, in general, notions of identity are dynamic, diverse, and therefore difficult to interpret (Brubaker and Cooper 2000). Hence, as a starting point, the Cypriot evidence will be regarded as representing a distinct 'cultural sphere'. However, possible influences, adoptions, and adaptations from surrounding cultures will be considered and discussed.

\section{Late Cypriot Cemeteries and Mortuary Practice}

While in the Early and Middle Cypriot periods burials and habitation areas were separated (see summary in Keswani 2004, pp. 39-41; see though the reservations expressed by Webb 2018), the Late Bronze Age mortuary evidence is very diverse: cemeteries from the Middle Cypriot periods were still in use, other extramural cemeteries were established at the end of the Middle Cypriot or the beginning of the Late Cypriot period (Keswani 
2004, p. 86), but associated larger settlements have not been found. In most urban centres, e.g., Enkomi, Toumba tou Skourou, Alassa, Kalavasos or Kition, the tombs are located inside the settlement, often immediately next to residential, administrative or workshop areas, in courtyards or open spaces (see summary in Keswani 2004, pp. 86-88). At first sight, Hala Sultan Tekke seems to represent an exception, as both extra- and intramural burials were found (see below). However, as will be demonstrated below, the dichotomy of intramural versus extramural needs to be questioned (see already Webb 2018). A long-term use of the tombs is still characteristic of Late Cypriot burial practices, as well as collective burials and complex multi-stage treatments of the deceased (Keswani 2004, 2012a). Hand in hand with the social, political, and economic transformations during the Late Bronze Age, i.e., the intensification of copper production and export, long distance trade, the development of urban centres and the increased interactions with surrounding cultures, it seems likely that specific practices underwent transformations, and some may have been adopted from other cultural spheres.

Emerging élites are inter alia expressed in richly furnished tombs containing items of social prestige (e.g., Keswani 1989, 2004, pp. 241-45, Table 5.11). Only in the 12th century BCE, i.e., the Late Cypriot (henceforth LC) IIIA, a decline of valuable items within the tomb inventory and the appearance of single (shaft) graves can be observed (Keswani 2004, pp. 118-19; see also the LC IIIA Tomb 23 from Hala Sultan Tekke in Niklasson 1983, which, however, contained numerous precious bronze objects). In the subsequent LC IIIB (end of 12th century-1050 BCE), which will not be discussed in the present article, funerals were carried out as 'public spectacles' (Keswani 2012a, p. 321) with excessive numbers of tomb objects and valuable prestige items (e.g., Karageorghis 2016; Karageorghis and Raptou 2016, 2019).

Besides burials and funerals, mortuary practice may also include a range of activities taking place in connection with the burial, as well as ancestral rites (Morris 1991; Charles and Buikstra 2002; Silverman 2002). The evidence from Hala Sultan Tekke offers the possibility to study a cemetery in a wider context and as an area where a multitude of different and recurrent rituals and activities were carried out.

\section{The Case of Hala Sultan Tekke}

The discovery and exposure of tombs was one of the main aims of the British Museum excavations by Henry B. Walters and John W. Crowfoot in 1897 and 1898, respectively (Bailey 1976). Unfortunately, there are only vague notes about the location of the more than 60 tombs exposed (Bailey 1976, Plate Ia, b). According to these, Walters' area is north-west and (one of) Crowfoot's to the south-east of Area 23 (see location in Figure 2; also Samaes and Nys 2010, p. 223, Figure 2). If these rough indications are correct, both areas are just outside the densely built city centre, which could be pinpointed and characterised thanks to a large-scale magnetometer survey carried out in 2017 (Fischer 2020, p. 192, Figure 2b). Five intramural tombs dating mainly to the LC II (Tombs 20-22, 24) and LC IIIA (Tomb 23) were found in Areas 8 and 23 (see Figure 2) in the 1970-1990s (Åström 1983; Niklasson 1983; Åström and Nys 2007). An LC IIA-B tomb was unearthed in CQ2 in the course of the renewed excavations (Fischer and Bürge 2018a, pp. 124, 129-34). Additional Late Cypriot tombs, some of which cannot be exactly located today, were found during rescue excavations along the channel and the road next to the mosque and under the parking lot of the mosque (Karageorghis 1976, 1983, p. 915; Samaes and Nys 2010). 


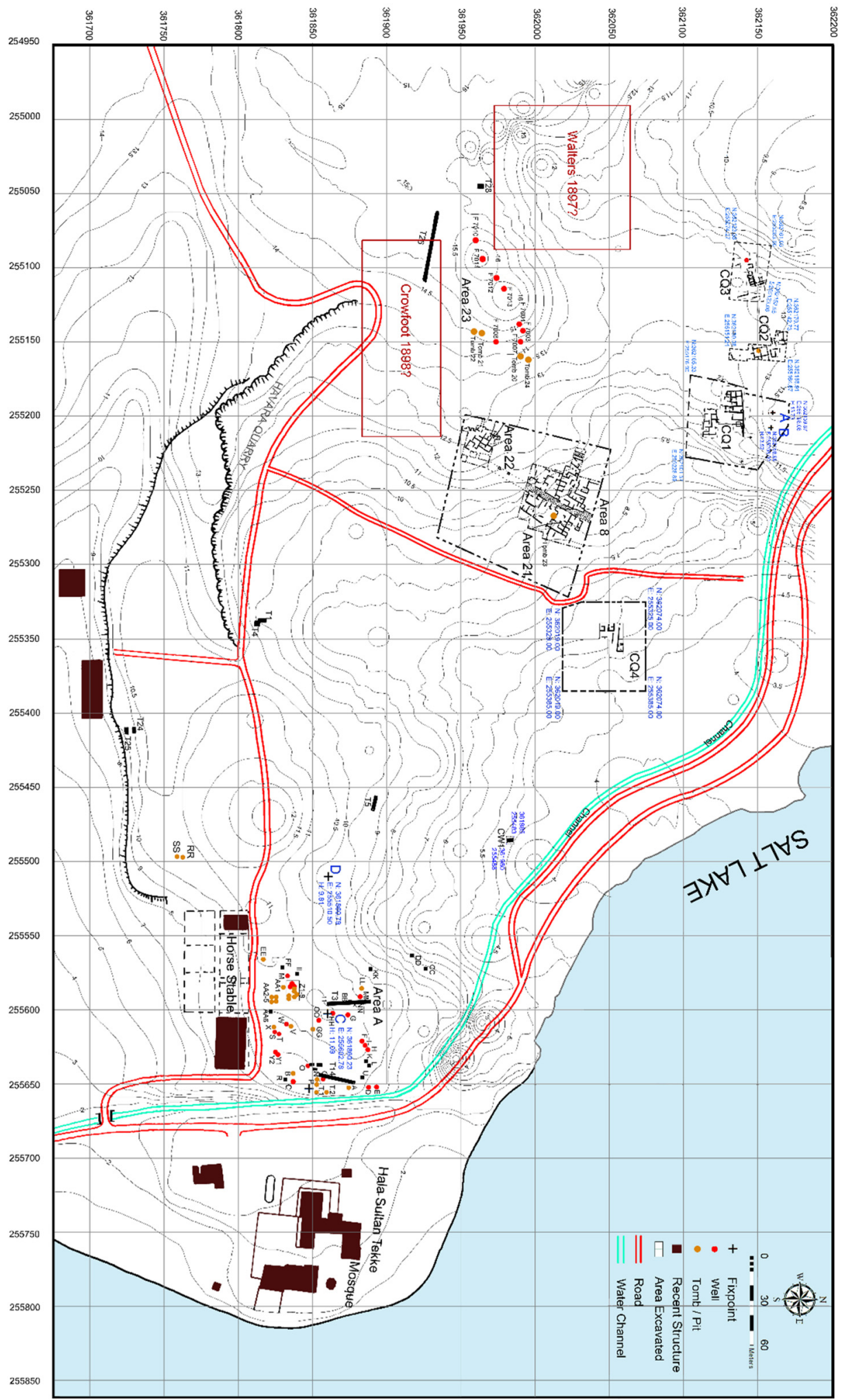

Figure 2. Overview over Hala Sultan Tekke and excavated areas (drawing by M. Al-Bataineh with additions by the author).

The existence of a large extramural cemetery, Area A, along with intramural burials at Hala Sultan Tekke, could be confirmed by the results of the 2017 magnetometer survey (Fischer 2020, p. 192, Figure 2b). Additional excavations substantiated the period of use from the earliest occupation of the city at the beginning of the Late Cypriot period until the 
end of the LC IIIA, i.e., in the mid to second half of the 12th century BCE, when the city was destroyed and abandoned, never to be occupied again. Area A is located just southeast of a structure, possibly a city wall or at least a small rampart (Fischer and Bürge 2020, pp. 90-91), and seems to continue beyond the channel and the road towards the mosque. Today, the area of Hala Sultan Tekke is relatively flat with differences of not more than $12-15 \mathrm{~m}$ between the highest points located mainly in the western and north-western parts of the city (Area 23 and CQ1) and the north-eastern part (e.g., CQ4), which gently slopes down towards the shore of today's Salt Lake. Although the Bronze Age coastline has not been determined yet (cf. Devillers et al. 2015), it is reasonable to assume that the ancient coast and the harbour were located in the area of the Salt Lake, which was connected to the sea in the Late Bronze Age (Morhange et al. 2000) and silted up some time after the end of the Late Bronze Age. Consequently, Area A, located in a presumably flat area close to the shore, must have been visible from the sea and vice versa.

Area A is not only interesting because it represents the only hitherto known Late Cypriot 'extramural' cemetery, which can be associated with one of the urban centres, but also because numerous wells with striking fillings and possible ritual pits were excavated mainly in the most recent seasons of excavation. A detailed publication of all features is forthcoming and some of them have been presented in preliminary reports (see summary in Bürge 2017). Therefore, only selected contexts will be presented and discussed, which may help to understand ritual activities in connection to burials and commemoration: these are subdivided into three main types based on contents and way of deposition, although there might be types that are mixed or reflect yet more activities performed in this area.

\subsection{Pits Containing Depositions of Complete Objects}

Four of this type of pit have been excavated at the site (Pits B, P, Z6 and Z7; Bürge 2017, pp. 136-41; Fischer and Bürge 2018b, pp. 49-50). Three (Pits B, Z6 and Z7) can be dated to the LC IIC, i.e., the 13th century BCE, while the material of Pit B is best placed in the LC IB, i.e., the 15th century BCE. The pits have circular shapes with diameters of 1-1.5 m. With the exception of one reused well (Z6) the others have depths of roughly 2-3 $\mathrm{m}$, which is not sufficient to reach groundwater. The reused well, Z6, is deeper but has not been excavated to groundwater level. In contrast to the other pits, it has circular recesses cut in at regular intervals, which are characteristic of the wells at the site and facilitated the access to the shaft for cleaning and maintenance (Fischer and Bürge 2018b, p. 45).

The stratigraphy reveals that up to three different acts of deposition took place within the same pit (Figure 3), most likely quite close in time. The uppermost deposits are in two cases (Pits B and Z6) sealed by an ochre-coloured layer (Figure 4a). The deposited artefacts are complete or almost complete and consist of locally made (Figure 4b: 1-2; Figure 5: 1-2, 8, 11) and imported fineware vessels (Figure 4b: 3-5; Figure 5: 3, 9-10), cooking vessels, lamps and wall brackets, loom weights, a spindle, or distaff (Figure 5: 13; see also Fischer and Bürge 2018b, p. 48, Figure 16.9) and a figurine of a female (Figure 5: 6) and a bovine rhyton (Figure 5: 7). Some faunal remains are worked or modified, such as incised scapulae of Bos (Figure 5: 5) and Ovis/Capra, ground down astragali of Ovis/Capra (Figure 5: 12) and fragments of elephant ivory. Other remains include mainly bird, fish, and shells, while botanical material is scarcely preserved. 



Figure 3. Plan and section of Pit B (drawing by M. Al-Bataineh with additions by the author).

All in all, the contents of these pits are not very different from Late Cypriot tomb inventories (see synopsis in Keswani 2004, pp. 226-48, Tables 5.8-5.13). However, frequent burial gifts, such as personal adornment or weapons are absent and, most importantly, there are no human remains. So far, no comparable contexts have been found in Late Bronze Age Cyprus and the combination of utilitarian items, textile production tools, tableware, and objects with cultic connotation, i.e., notched scapulae, ground down astragali, figurines, and rhyta, is unique. Jennifer M. Webb (1999, p. 249 with further references) has suggested that incised scapulae were used for scapulomancy, i.e., divination based on specific features of the bone. It has also been suggested that these were used as musical instruments (Karageorghis 1990), perhaps similar to rasps known from Central Europe already in the Palaeolithic period (Morley 2005, pp. 214-15), but the notches are not very deep, quite irregular, and too distant from each other to produce an acceptable sound-beside the 
fact that the scapulae do not show any use-related wear (see also Webb 1985, p. 324; for further discussion and interpretation see also Zukerman et al. 2007). In any case, they occur mostly in ritual contexts (Webb 1999, p. 249; Reese 2002). Possible functions of the astragali include again fortune telling (astragalomancy) indicated by the way the bones fall but they may also have functioned as gaming pieces (Gilmour 1997; Webb 1999, p. 250). Nude Base-ring female figurines, of which two general types exist (Webb 1999, pp. 209-11), are fairly standardised, most likely depict a divinity (Budin 2009) and, at least one of the types, clearly alludes to fertility (Webb 1999, pp. 209-11; for more recent interpretive approaches see Alexandrou 2019; Steel 2021). These, as well as bovine rhyta, were mostly found in cultic structures and less commonly in tombs (Webb 1999, pp. 209-11, 216-19; see though recently Alexandrou 2019, p. 202; see below their occurrence in Tombs RR and SS at Hala Sultan Tekke; also Fischer and Bürge, Fischer and Bürge).
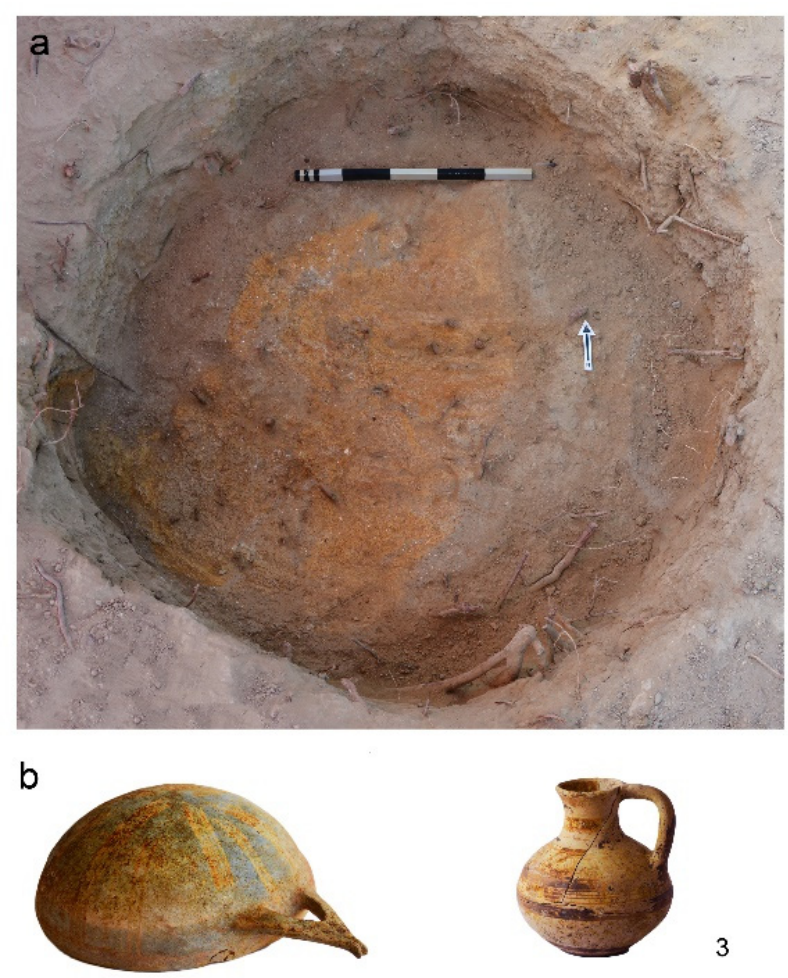

1
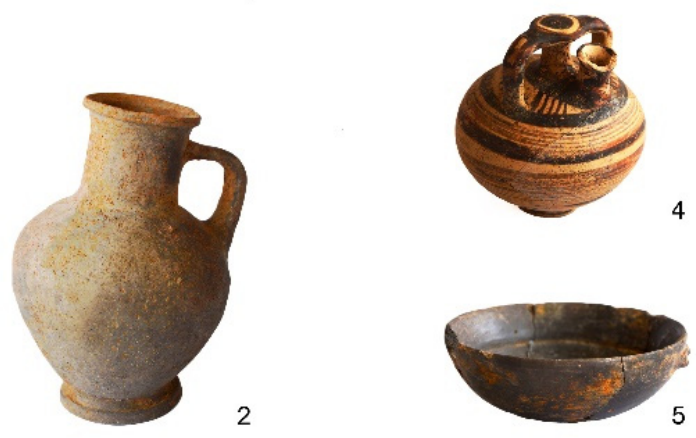

Figure 4. Pit B: (a) Ochre layer covering the uppermost deposition; (b) selected finds (photographs by P.M. Fischer and the author). 

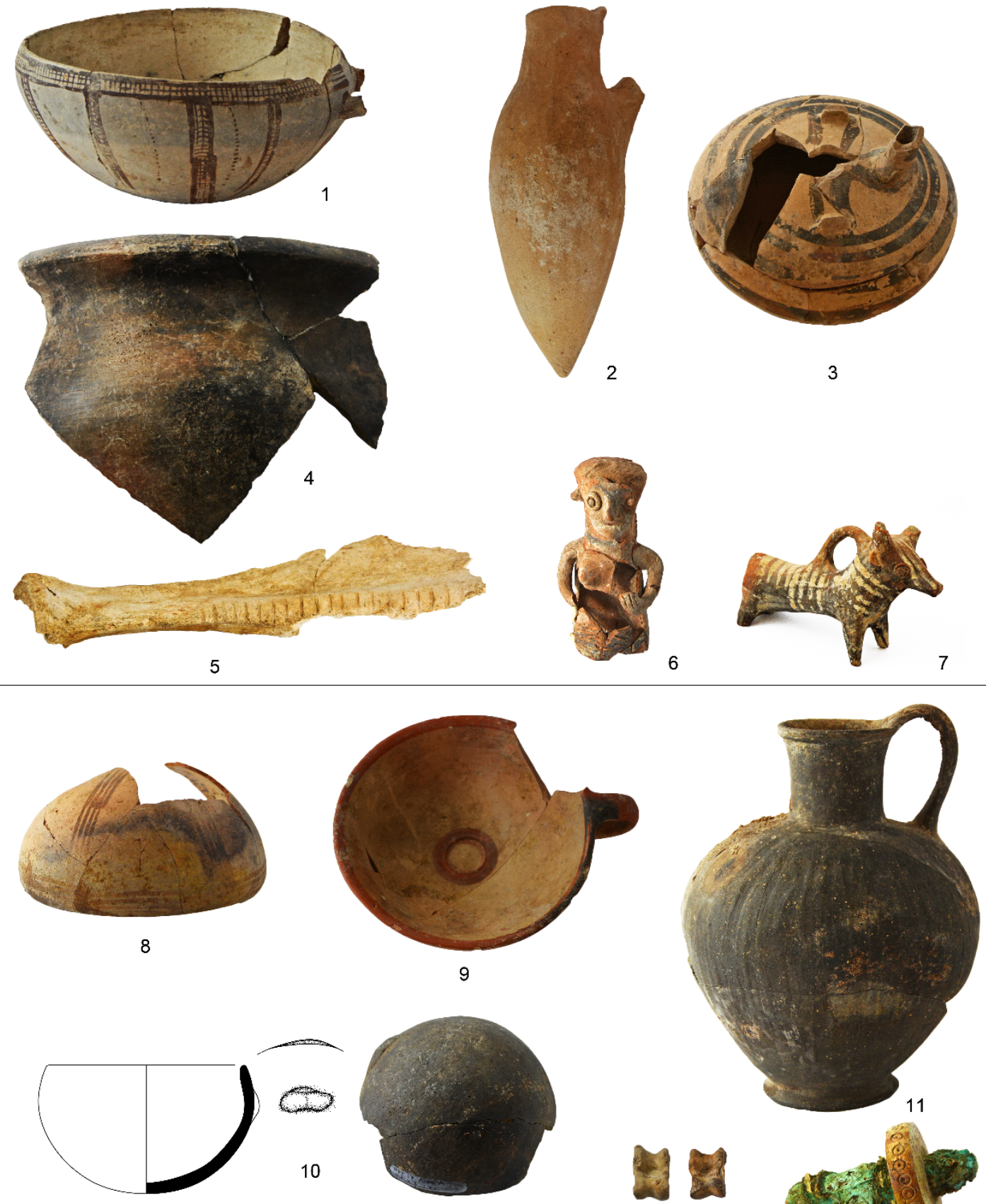

12

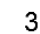

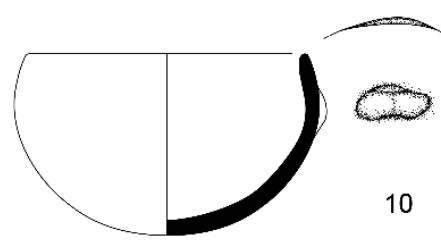



8





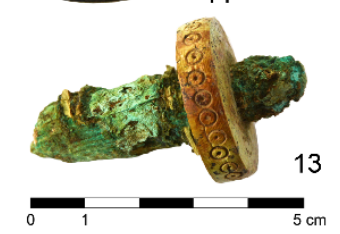

Figure 5. Selected finds from Hala Sultan Tekke, Pit Z6 (upper part) and Pit Z7 (lower part) (photographs by P.M. Fischer and the author, drawing by the author).

The tableware from the pits consists of locally produced finewares (Figure $4 \mathrm{~b}: 1-2$; Figure 5: 1-2, 8) and, in the case of the more recent pits (B, Z6, Z7), Mycenaean (Figure 4b: 3-4; Figure 5: 9), Minoan (Figure 5: 3) and Sardinian imports (Figure 4b: 5; Figure 5: 4, 10). Both open and closed vessels are represented, but it is interesting to note that bowls (together with other open vessels such as cups and kylikes) prevail in all pits (Figures 6-8). The second largest group is that of serving vessels (jugs) and small containers (juglets, small stirrup jars, alabastra). Vessels for food preparation, i.e., cooking pots, baking trays, and basins occur as well but never in large quantities. Storage and transport vessels, i.e., pithoi and Canaanite jars, are only preserved in fragments. While Sardinian imports, five bowls 
and a large fragment of an open vessel which resembles a cooking pot, are present in all three contexts, the quantity of Mycenaean (and Minoan) imports varies slightly, while the vessel types comprise open eating/drinking vessels (bowls, cups, kylikes) and containers for small precious substances (alabastra, stirrup jars, juglets): Pit B contained six vessels (a shallow cup and an alabastron, two stirrup jars and juglets), Pit Z6 only a shallow bowl and a Minoan small squat stirrup jar, and Pit Z7 an almost complete and three larger diagnostic fragments of bowl(s), a kylix, a shallow cup, and a complete and a lower part of a juglet.

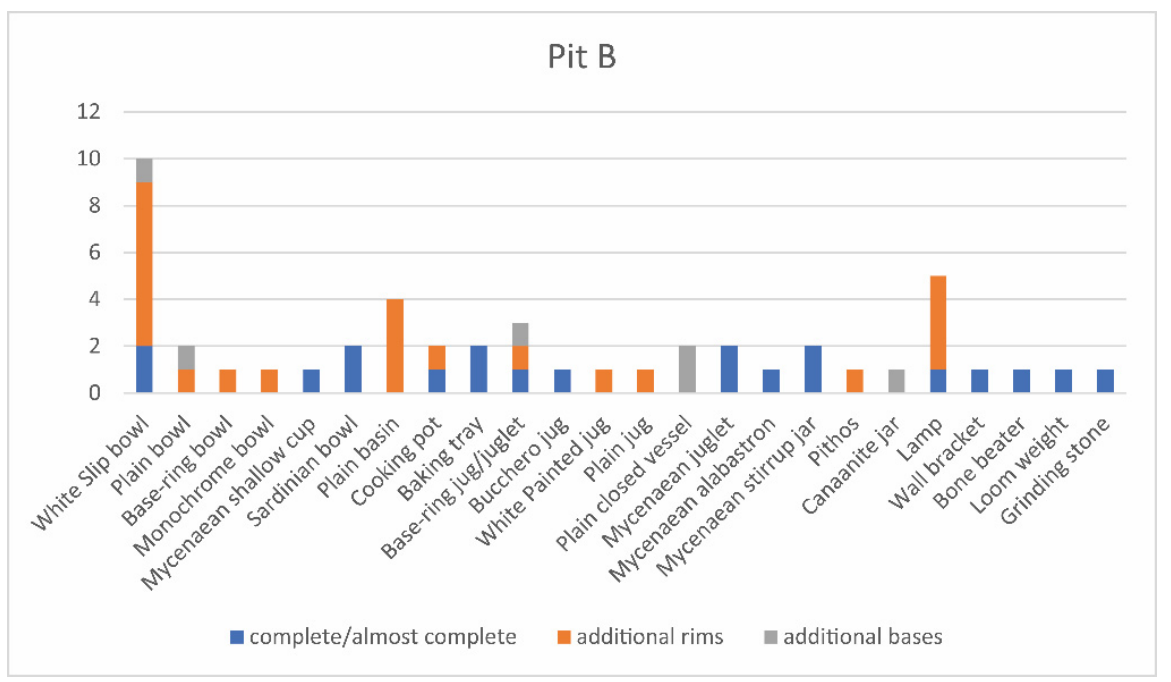

Figure 6. Distribution of finds from Hala Sultan Tekke, Pit B.

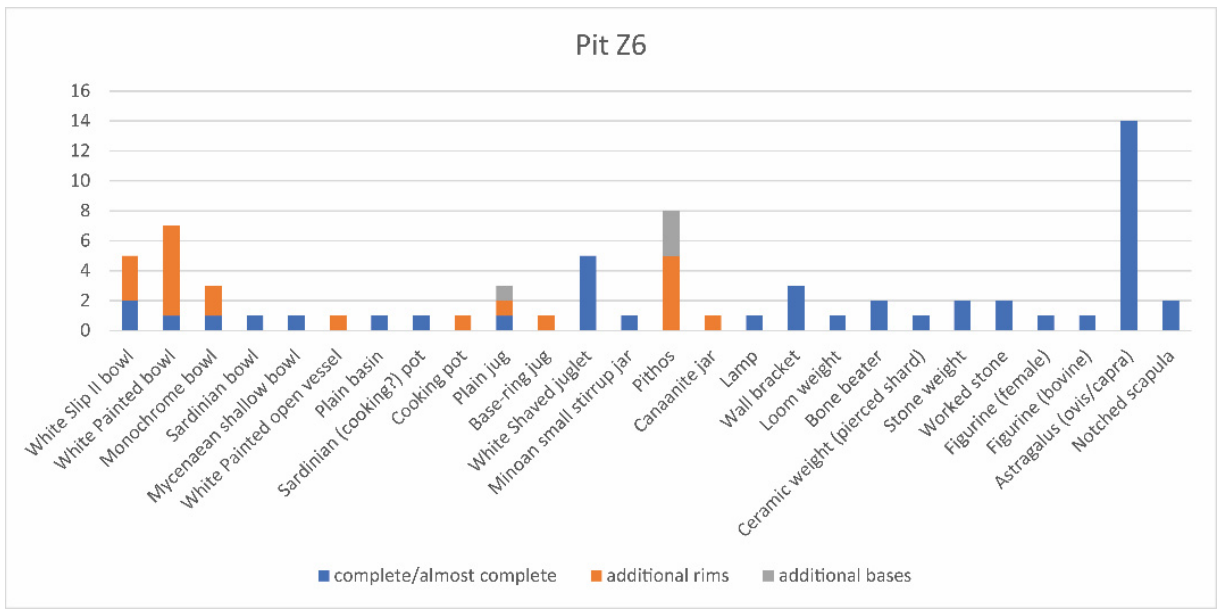

Figure 7. Distribution of finds from Hala Sultan Tekke, Pit Z6. 


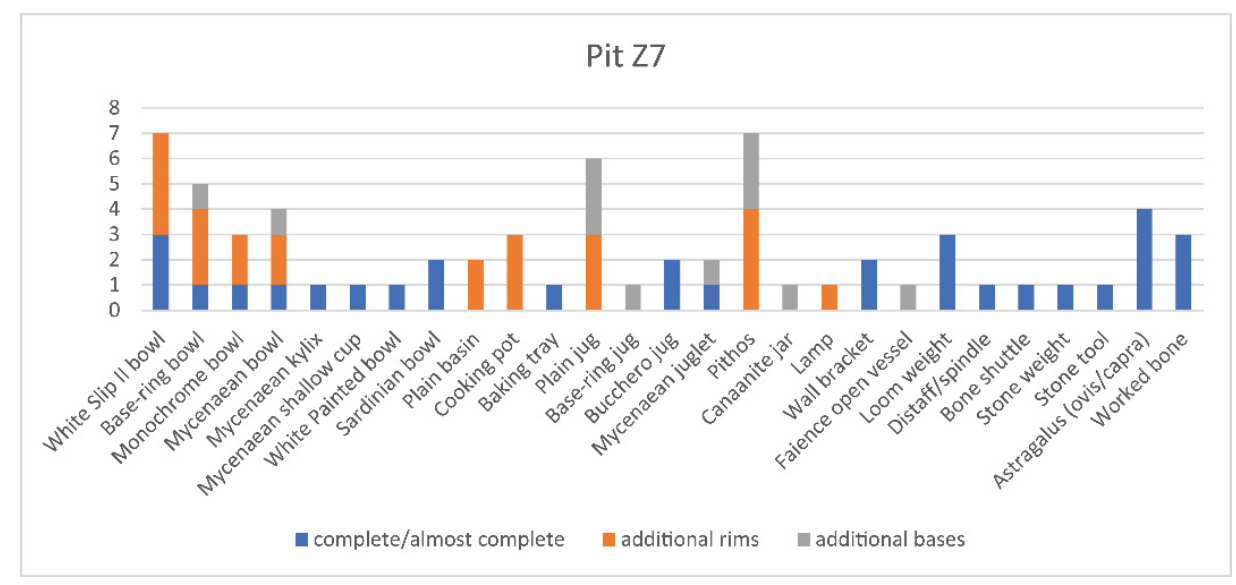

Figure 8. Distribution of finds from Hala Sultan Tekke, Pit Z7.

\subsection{Pits Containing Broken Fineware}

Four pits or wells containing exceptionally large amounts of broken fineware have been discovered in Area A. The well in Trench 1/4 was excavated in 1971-1972 (Öbrink 1983) and epitomises the misconception of this specific type of context: the well filling excavated down to a depth of $3.45 \mathrm{~m}$ consisted of over 10,000 fragments, of which around $75 \%$ are finewares of local production and Mycenaean and Anatolian imports, and $24 \%$ are Plain wares that may also comprise fine tableware (Figure 9). Since the material needs some revision concerning the identification of wares and the statistics, only preliminary observations can be made; while the large group of Base-ring vessels mainly comprise closed shapes (jugs, tankards), the Plain wares mainly include kraters, bowls, and jugs and White Slip is almost exclusively represented by bowls. The evaluation of the Mycenaean imports is somewhat more detailed (Öbrink 1983, p. 35, Table 2), yet based on sherd count (for a critique of this method and an alternative approach to pottery statistics see Bader 2010); closed shapes, mainly piriform jars and jugs prevail, whereas eating/drinking vessels such as bowls and kylikes as well as kraters are relatively rare. The material suggests a date in LC IIA-B/Late Helladic (LH) IIIA1-2, i.e., in the early 14th century BCE. Only ten fragments of cooking ware come from this well and very few pithos and Canaanite jar fragments, while other types of objects are absent. Among the very few faunal remains are six bones of Equus asinus and ten marine shells (Reese 1998, p. 136). This peculiar context was interpreted as tomb material by Öbrink (1983, p. 31) but neither the absence of human bones and artefacts commonly occurring in burial contexts, nor the fact that all vessels were fragmented were further discussed.

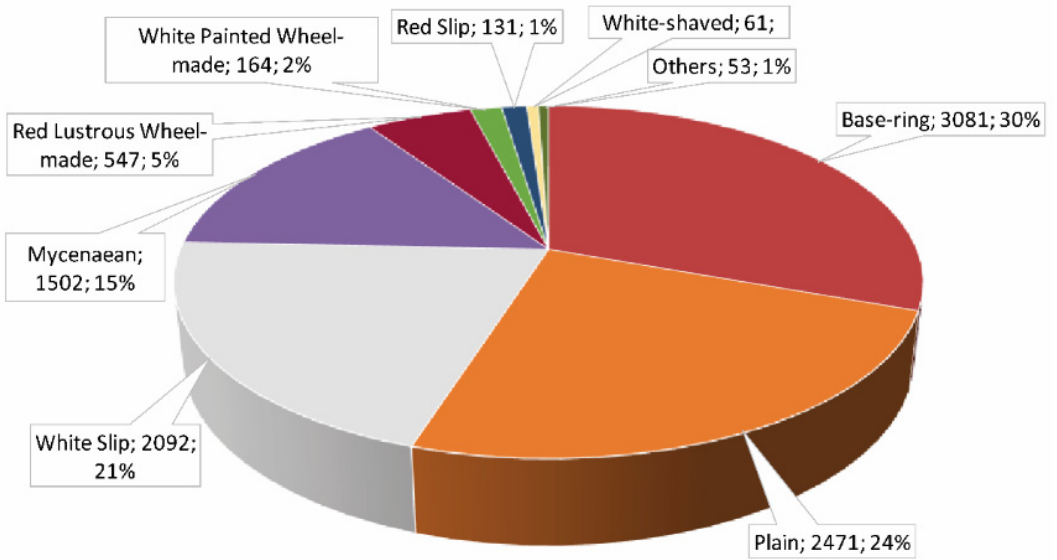

Figure 9. Hala Sultan Tekke, well in Trench 1/4: distribution of pottery classes according to Öbrink 1983 (based on sherd count). 
In the course of the renewed excavations at least three similar contexts, Well Q, Pit $\mathrm{V}$ and Pit GG, were found. Well $\mathrm{Q}$ is very similar regarding context and material (Bürge 2017, pp. 143-45), while Pits V and GG are relatively shallow and figure-8-shaped. Nevertheless, the large amounts of fragmented pottery, mainly finewares, the general lack of non-ceramic objects and the relative scarcity of faunal remains resemble the well in Trench 1/4. The material from the other three pits/wells has not yet been studied completely but preliminary analyses suggest a relatively long timespan represented in the pottery ranging from LC IIB-C/LH IIIA2-B, i.e., ca. 1350-1200 BCE (Bürge 2017, pp. 143-45; Fischer and Bürge 2018b, p. 53). However, all four pits have in common that matching pieces are distributed throughout almost all levels and areas within each feature, which hints at one single act of deposition. In addition, some vessel parts show evidence of deliberate breakage and none of the vessels could be completely reassembled, as despite careful excavation and extensive sieving some fragments were still missing (Figure 10).

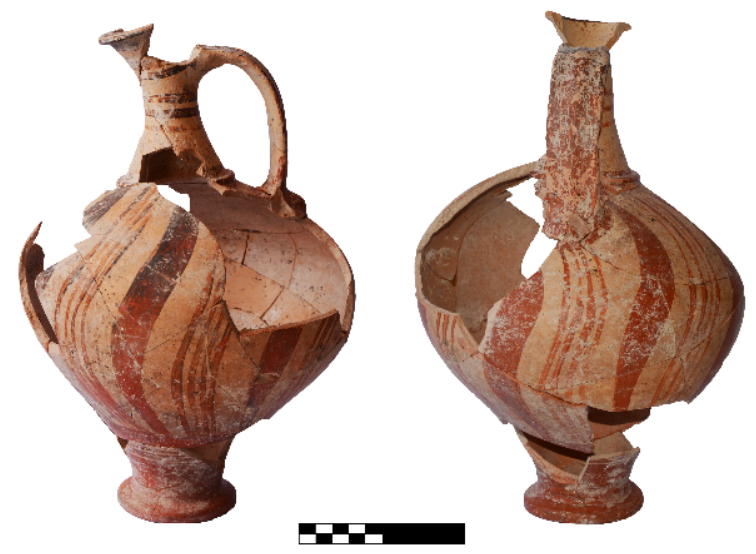

Figure 10. Mycenaean (LH IIIA) jug from Hala Sultan Tekke, Pit V, showing missing fragments (photograph by the author).

In summary, these features do not contain typical tomb inventories and human remains are absent. The contents rather seem to represent ritual consumption and, as the small number of animal bones and botanical remains indicate, that of liquid substances. A preliminary evaluation of vessel types revealed that open shapes are well represented in White Slip, Base-ring, and Plain wares, whereas Mycenaean imports mainly contribute to the repertoire of closed shapes (jugs, piriform jars). The same applies to Anatolian Red Lustrous Wheel-made vessels, which are predominantly spindle bottles (regarding the most likely Anatolian origin of this ware see, e.g., Kibaroğlu et al. 2019; Kozal). The long timespan reflected in Pit V may either point to an extended use life of specific vessels or to the possibility that the pottery was collected elsewhere after each consumption event and finally deposited in one single event, which may also explain the missing fragments.

\subsection{Pits Containing Broken Pottery and Larger Amounts of Faunal Remains}

The third group of pits is more diverse and will be discussed only exemplarily using Well $\mathrm{F}$ as a 'model'. Here it seems that mainly wells have been used to discard pottery, other objects, and animal bones. The numerous wells at Hala Sultan Tekke, all characterised by the presence of climbing holes, have depths of more than $10 \mathrm{~m}$ but only very few could be excavated down to the bottom (Åström 1998). Nevertheless, an evaluation of the material is meaningful even in partly excavated wells, since the material is mostly concentrated in the uppermost levels of the shaft. Well F yielded over 30 complete or almost complete objects, among them a possible bronze vessel, a scarab, loom weights, and a bone beater and numerous ceramic vessels (see a summary in Fischer and Bürge 2016, pp. 47-49) in addition to 1285 pottery fragments (Figure 11). Looking at the rim and base statistics (MNI) of pottery types and shapes, we see a high overrepresentation of bowls $(n=116$; Figure 12). Most of them $(n=76)$ are of White Slip II ware, followed by Plain ware $(n=20)$ 
and Base-ring $(n=8)$ and single examples of other wares (White Painted, Red Slip, Red Lustrous Wheel-made). The second largest group are jugs $(n=42)$, mainly of Plain ware, Bucchero, and Base-ring, followed by Plain ware basins $(n=11)$ and lamps $(n=6)$. Cooking pots, pithoi, Canaanite jars, juglets, and wall brackets occur only occasionally $(n \leq 4)$.

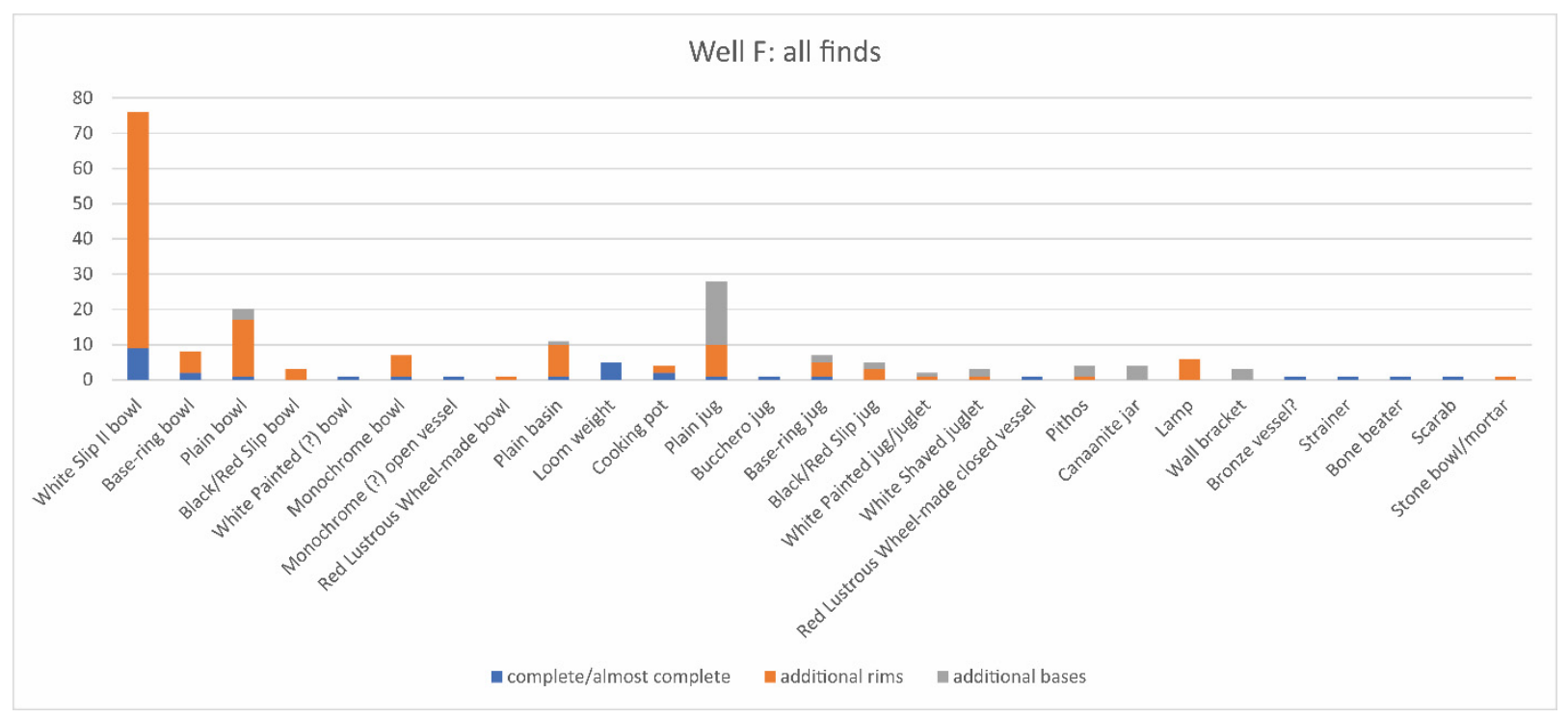

Figure 11. Hala Sultan Tekke, Well F: distribution of finds.

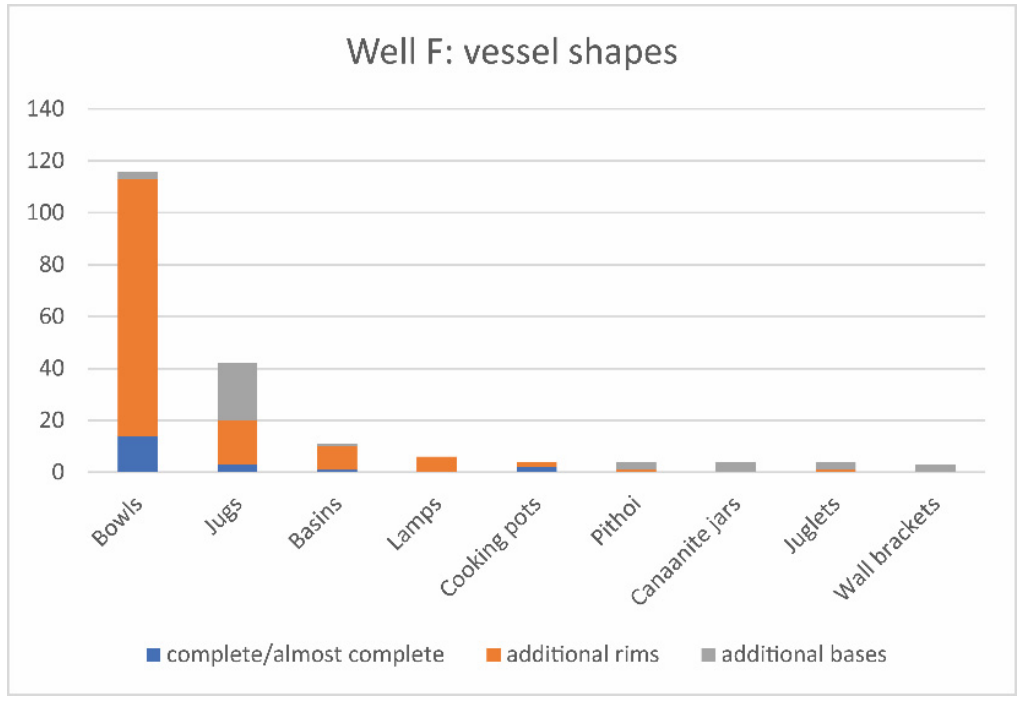

Figure 12. Hala Sultan Tekke, Well F: distribution of vessel shapes.

Besides the considerably smaller number of pottery fragments and objects, the main difference to the pits described above are the faunal remains: Well $\mathrm{F}$ contained numerous remains of mainly Ovis/Capra, Bos, Canis, small mammals, birds, fish, and molluscs, among them several hundreds MNI of Hexaplex which were crushed. Although a final evaluation of the faunal remains is forthcoming, the preliminary results show that among the Ovis/Capra and Bos remains numerous cut marks of meat-bearing and other parts are present. Meat consumption and the (symbolic) use of specific animal parts certainly took place in Area A, since large amounts of animal bones as well as distinct skeletal parts, such as skulls, horns or even almost complete animals-mainly cattle, sheep/goat, equid and dog have been discarded in other wells and pits in the area (e.g., Fischer and Bürge 2015, p. 47, Figure 26). 


\section{Mortuary Rituals and Activities at Hala Sultan Tekke, Area A}

How do these contexts relate to each other and how are they connected to the tombs in the same area? It seems obvious that the pits reflect different types of activities: while the pits with complete objects are the results of careful depositions, those with fragmented finewares and other objects were filled up by throwing complete or already broken vessels after ritual consumption. None of these contexts is consistent with tomb inventories and the frequent assumption that similar deposits often found in wells or pits represent the remains of looted tombs (e.g., Hala Sultan Tekke: Öbrink 1979, p. 1; 1983, p. 31; Kouklia Mantissa: Karageorghis 1965, p. 158; Enkomi: Lagarce 1986, pp. 57-58) is not tenable.

The deposits in Area A cover the period from LC IB to LC IIC, which is consistent with the main use of the cemetery. The two reused wells of the LC IIIA, where several individuals were buried with only very few associated objects or personal belongings (Stolle 2016; Fischer and Bürge 2018b, p. 50), are not discussed in the present paper but may perhaps express changes in customs and society in the transformative period of the 12th century $\mathrm{BCE}$ (Fischer and Bürge). Analogous to the common Late Cypriot burial practice, the LC I-II tombs in Area A contain numerous burials and show clear evidence of different stages and degrees of post-mortem treatment and long periods of use, often spanning a few centuries (Bürge and Fischer 2017; Bürge 2017, Fischer and Bürge). The activities taking place in a cemetery therefore do not only consist of funeral rituals. There may have been extended periods of celebration or periodic events between the first placement of the corpse (in or outside the tomb) and secondary treatments or depositions. Tombs were recurrently opened and closed again to deposit additional corpses, and specific rituals took place during each of these stages. In addition, rituals of commemoration or activities connected to ancestral cults, which are certainly more restricted and circumscribed than funerals (see also Webb 2018, p. 216; 2019, p. 171), may have occurred both simultaneously and/or independently from the funerals per se, and these may explain the function of the pits with complete objects: while they do not seem to contain animal sacrifices or food offerings, the deposited objects are of symbolic value and the few relatively small drinking and serving vessels indicate small-scale drinking of restricted groups or libations.

Since the meaning of the incised scapulae, the modified astragali, the female figurines, and animal rhyta is not entirely clear, it is difficult to assess what exactly these symbolise when deposited in the pits. However, it is interesting to note that these objects do occur in Late Cypriot tombs, albeit not very frequently. Two examples are at Hala Sultan Tekke; one is Tomb RR (Fischer and Bürge 2020, pp. 91-96; Fischer and Bürge), where four Cypriot Base-ring figurines of females and one Minoan female were deposited, besides a fragment of an incised scapula and ground-down astragali. The other is Tomb SS, where inter alia a Base-ring bovine rhyton was associated with one of the burials (Fischer and Bürge). It cannot be excluded that the pits with complete objects are related to ritual pits known from Hittite sources which connect the living with chthonic deities (Collins 2002). Although it is often problematic to introduce interpretive terms, as these may hamper an unbiased approach, for the time being this type of pit will be termed 'offering pit', which may comprise the notion of votive offering, commemoration, or ancestral cults, as well as other possible aspects like necromancy or 'symbolic sacrifices'.

The deposits of broken fineware clearly display collective consumption, most likely of mainly liquid substances. However, the apparently single event of final deposition contradicted by the long timespan represented in the pottery may only be explained when looking at the nearby tombs and specifically the recently (2020-2021) excavated Tomb SS (Fischer and Bürge, Fischer and Bürge): the roughly pentagonal pit of $4.5 \mathrm{~m}$ in diameter contained (at least) two deposits of broken pottery covering the burials. While the heap-like upper deposit (L121; Figure 13) is the result of a single event of throwing vessels into the open tomb pit, the lower one (L133; Figures 14 and 15) has been created by depositing vessels on top of the most recent burials. The main difference in the deposits is the degree of fragmentation, which is considerably higher in the upper deposit, while the pottery in the lower is in most cases intact or broken on the spot in large fragments. However, 
in contrast to the evidence from the fineware pits discussed above, even the relatively fragmented vessels of the upper deposit could be completely reassembled.

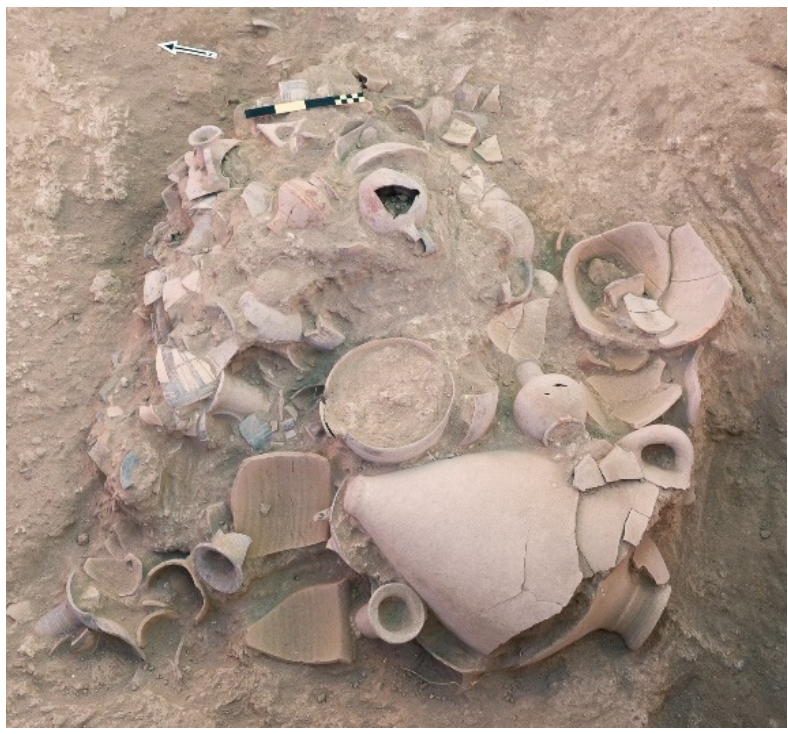

Figure 13. Hala Sultan Tekke, Tomb SS; photo of upper pottery deposit L121 (photograph by P.M. Fischer).



Figure 14. Hala Sultan Tekke, Tomb SS; preliminary plan of lower deposit (by A. Buhlke). 


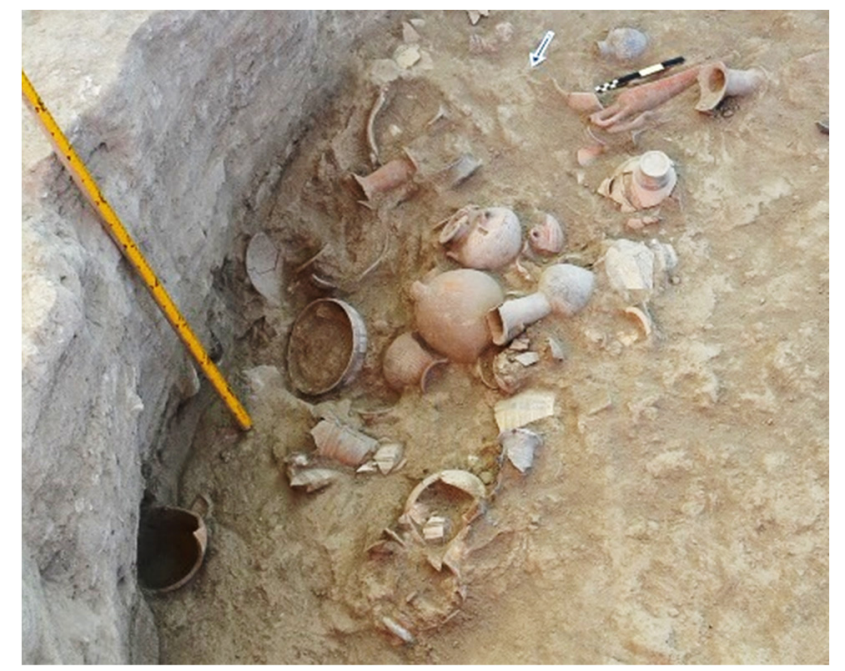

Figure 15. Hala Sultan Tekke, Tomb SS; photo of part of lower pottery deposit L133 (photograph by P.M. Fischer).

Regarding the type of material, these two deposits are almost identical and comprise (at the current state of processing) around 250 complete vessels of almost exclusively fineware. There is one Canaanite jar in each deposit, whereas only a few fragments of cooking vessels were found. The main pottery classes represented include local tableware, mainly bowls, jugs, and juglets of Base-ring, White Slip, White Shaved, and Plain ware and spindle bottles and bowls of Anatolian Red Lustrous Wheel-made ware. More than a third of the Mycenaean and Minoan imported vessels are miniature piriform jars. Other shapes include mainly kraters-some of them with pictorial decoration-stirrup jars, juglets, and alabastra, whereas open vessels - bowls and kylikes-are represented in quite low numbers, and only one rhyton was deposited.

The only faunal remains consist of various molluscs, most of them complete Bolinus brandaris and Hexaplex trunculus, i.e., purple snails, as well as a Base-ring jug that contained fish bones. The pottery is best placed in LH IIIA2 and LC IIA2-B, i.e., the second half of the 14th century $\mathrm{BCE}$, and the homogeneous composition of the pottery corpus suggests that both deposits were placed rather close in time. While these deposits certainly deserve further discussion under various aspects and the processing of the material is still ongoing, it seems to reflect one or perhaps more rituals of tomb closure. Here, too, the material suggests communal drinking rather than meat consumption-unless the meat refuse was discarded elsewhere.

Hence, the most probable explanation for the deposits of broken fineware are periodic tomb openings and closures and the necessity of clearing the tomb and removing the deposited items before a new interment could take place, which may have ended in one or more feasts, i.e., a 'a form of public ritual activity centered around the communal consumption of food and drink' (Dietler 2001, p. 67), perhaps primarily for commemoration of the deceased but also for defining social relations (e.g., Steel 2004; Hayden 2009). However, consumption of food and drink as meaningful epitomisation of mnemonic device as well as to create remembering and forgetting is only one activity that took place. Others may have included singing, dancing, consumption of alcohol and other psychoactive substances, and the symbolic killing and sacrifice of pottery and other objects (see also Hamilakis 1998; Steel 2004). It is important to point out that objects used in ritual performances most likely were not simply 'discarded' but there might be highly ritualised, specialised, and complex procedures of handling ritual waste (e.g., Ekroth 2017).

The presence of large skeletal parts of animals and non-meat bearing parts in some of the wells and shafts of Area A indicates that slaughtering and butchering took place close by. In addition, a pit containing one or more pithoi and numerous White Slip II bowls (Pit EE; Fischer and Bürge 2018b, p. 53) may have been used to store food and/or liquid items. 
There has been much speculation about the density of wells in this area (e.g., Fischer and Bürge 2017, p. 209) and despite the supposedly short life cycle of each well due to the soil conditions and the risk of saltwater intrusion, the preparations for and the ritual activities themselves certainly required continuous access to fresh water.

\section{Mortuary Landscapes, Feasting and Consumption in Late Bronze Age Cyprus}

The combination of tombs and wells characteristic of Area A is repeated in the intramural Area 23 of Hala Sultan Tekke (see location in Figure 2), which today constitutes the highest elevation of the site. Due to intensive ploughing during the past decades, no architectural remains are visible-neither at the surface nor on the magnetometer map. We can therefore not exclude the possibility that this area was covered with buildings, but it is likely that it was an open space inside the city, where similar rituals and performances were carried out as in Area A. Webb (2018) has recently challenged the concept of intraversus extramural location of a cemetery by taking a closer look at the development of mortuary space in relation to residential buildings and other architectural units. She came to the conclusion that in many Late Bronze Age urban centres, such as Enkomi, Toumba tou Skourou, or Maroni, most 'intramural' tombs were primarily located in open spaces. If they were found immediately next to or below buildings, these mostly postdate the tombs. Hence, the 'boundary between intra- end extramural burial was blurred and residential burial (i.e., burial in interior domestic space) was reserved for a small group of elites' (Webb 2018, p. 223). These observations entirely match the evidence from Hala Sultan Tekke. In addition, peculiar fills of pits, e.g., a fragmented fineware deposit in Area 22 (Öbrink 1979; see location in Figure 2), a residential area, may also be the result of feasting or clearing tomb deposits, although, admittedly, no tomb has been found in the vicinity and the sherds may also reflect any other (ritual) consumption.

In recent years, mortuary feasting and drinking in Bronze Age Cyprus has been suggested and discussed in connection with contexts of different periods and regions of the island and it is most likely that this took place mainly outside of the tombs, not only in the Early and Middle Cypriot (see Webb and Frankel 2008, p. 288) but also in the Late Cypriot period (possibly with some exceptions, e.g., Tomb 66 at Enkomi, see below). In fact, the tombs at Hala Sultan Tekke also contained various meat bearing animal remains (besides parts of skulls or horns which may have had symbolic properties; see above), partly inside vessels (e.g., bones inside a White Slip II bowl and a jug with numerous fish bones in Tomb RR; see Fischer and Bürge 2020) and partly deposited next to the burials and may represent either food offerings to the deceased, to supernatural forces, chthonic deities, or perhaps 'symbolic participations' in feasting by the deceased together with the surviving members of the family or society. However, the tombs do not seem sufficiently spacious to enable celebrations with the participation of larger groups of persons.

In this sense, other Late Bronze Age contexts deserve a closer look. A possible forerunner of these could be at the site of Korovia Palaeoskoutella (see location in Figure 1), where numerous grave tumuli with buttressed chambers, which are unusual in the prehistoric Cypriot record, were found (Gjerstad et al. 1934, pp. 416-38; Webb 1992, pp. 92-94). The most recent material can be dated to the Middle Cypriot (MC) III to LC I period (Webb 1992, pp. 92-93). Associated pits and basins filled with faunal remains, pottery sherds, ash, and dark sticky soil have been interpreted as installations for libations, food and drink offerings, funerary meals, or sacrifices carried out in connection with the surrounding burials (Webb 1992, pp. 93-94).

The character and settlement topography of the Late Bronze Age occupation at Palaepaphos (Figure 1) is not easy to understand due to erosion and later building, settlement, and agricultural activities (Iacovou 2008, p. 266). However, there are unambiguous material remains from the MC III to LC I transition (Georgiou 2019, p. 195) and mainly tomb and settlement material prove that the site was settled during the entire Late Bronze Age and that it originated from various small clusters at different localities (Iacovou 2008, pp. 265-66). Today, mainly tombs and some wells are known from this period; at the local- 
ity of Mantissa a number of shafts, most likely not wells, were found during construction work. One of these was excavated and revealed a deposit of more than 70 complete or almost complete vessels of tableware, almost exclusively bowls piled upon each other, which can be dated from the LC IIC-IIIA period, i.e., around 1200 BCE (Karageorghis 1965, pp. 157-84). Due to the close proximity of the shafts to tombs from the same period, the content of the shaft has been interpreted as material from looted tombs (Karageorghis 1965, p. 158) - although human remains are not reported. It is not clear if the shafts were located inside or outside the settlement but these shafts may attest to (mortuary) rituals similar to those from Hala Sultan Tekke. A peculiar LC IIIA well fill from the locality of Evreti, some hundred metres south of Mantissa, has recently been interpreted by Constance von Rüden (2016) as remains of feasting debris-possibly from a sanctuary, in which also crafts played an integral role (regarding the connection between workshops and sanctuaries see Webb 1999).

At Toumba tou Skourou (Figure 1), features with burnt material, faunal remains, and fragmented pottery were found above Tombs I and II, mainly dated to the LC I (Vermeule and Wolsky 1990, pp. 169, 245-46), i.e., around 1650-1525 BCE. These were interpreted as remains of funerary rituals, although the fact that these are located not within but on top of the burial layers may also point to ceremonies carried out later (see also Keswani 2012a, p. 317, n. 138), such as commemoration or ancestor cults. Besides many other tombs on the island, the discussion of which goes beyond the topic of the paper, it is interesting to note that a similar closing deposit as that of Hala Sultan Tekke, Tomb SS, has been found covering a LC I tomb at Ayia Irini Paleokastro (Quilici 1991). The fact that the enormous quantity of pottery on top of and partly intermingled with the remains of the most recent burials has simply been labelled as tomb gifts (Italian 'corredo'; Quilici 1991, pp. 135-49) and that the moved human remains have been interpreted as result of carelessness (Quilici 1991, p. 135) highlights the problem of previous research: tomb inventories have mainly been discussed under typological and chronological criteria, but possible groups of deposits within a tomb, the way and place in which artefacts and biofacts have been deposited is often not documented, yet it may provide plentiful information on all activities in connection with funerals, secondary burials, and rituals of commemoration. Possible ritual pits similar to those at Hala Sultan Tekke may have often been neglected or only briefly mentioned in excavation reports (see, e.g., Lagarce 1986, pp. 57-58 for a peculiar deposit in a reused well in Enkomi).

While the discussion of other feasting deposits in non-mortuary contexts (e.g., that at LC IIC Kalavasos Ayios Dhimitrios, Building X, for which see South 2008; also Steel 2004, pp. 290-92; or at LC II Hala Sultan Tekke, CQ1, for which see Fischer and Bürge 2020, pp. 80-82) goes beyond the scope of this paper, another interesting deposit, albeit not from a mortuary context, deserves further attention. In the Sanctuary of the Horned God in Enkomi, on Floor III of Room 10 (Dikaios 1969, pp. 171-220), which is dated to LC IIIA late to IIIB early (i.e., the late 12th century BCE), a total of 276 bowls were placed upside down in three piles-a deposit that can be linked to the final closure of the sanctuary. Room 10 is also the space where the famous bronze statuette of the Horned God was found (Dikaios 1969, pp. 177, 191-211, 524), although the circumstances of deposition of the statuette are not well understood (Webb 1999, p. 99). The deposited bowls are of Plain White Wheel-made ware, imitating traditional LC IIC bowls of hand-made Base-ring ware, in a period when the Cypriot drinking set had already been replaced by locally produced Mycenaean-type vessels (Jung 2011). Papasavvas (2014, p. 257) has interpreted this context as the creation of a mnemonic record within a conservative ritual tradition. In addition, he connects the inverted bowls to mortuary deposits, which are known, e.g., from Minoan Crete (with reference to Hamilakis 2008; Caloi 2011). This systematic ritual inversion, however, is not found in the deposits of Area A at Hala Sultan Tekke, not even in the contexts with complete vessels. The formal closure of the Sanctuary of the Horned God in Enkomi is symptomatic for the processes of the final abandonment of the entire settlement 
in LC IIIC and the ceremonies and rituals performed in this occasion may perhaps be compared to the final closures of tombs.

In summary, this very brief and limited review of mortuary feasting remains in Late Bronze Age Cyprus may provide an idea about the importance of mortuary rituals in society. The spatial arrangement and the question of whether tombs are located inside or outside habitation areas is perhaps not crucial for the manner and the location in which funerals were performed. Hence, both extra- and intramural tombs may be regarded as sacred spaces, and in both cases the possibility should not be excluded that these spaces also had a multitude of other purposes and connotations in the eyes of the local population. In the case of Hala Sultan Tekke, at least two burial areas could be determined, Area 23 inside the city and Area A outside. Both areas are located at prominent places, well visible within the city and/or from the sea. Unfortunately, it is impossible to assess the appearance of these cemetery areas in the Late Bronze Age. Tombs must have been marked in some way, since they were periodically reused throughout many generations. Other pits may have remained open for some time and may have been closed and concealed after the last deposition, which is also indicated by the ochre-coloured 'sealing' in some of these pits (see above).

\section{Discussion: Tradition and Insularity, Innovation and Connectivity Reflected in the Mortuary Programme}

As shown above, specific aspects of the mortuary programme of Late Bronze Age Cyprus seem to be consistent with Middle Cypriot (and even earlier) traditions. These traditions seem to be characteristic of the island of Cyprus (Keswani 2004, pp. 157-60) and contrast with those from surrounding areas (e.g., Pfälzner et al. 2012; Dakouri-Hild and Boyd 2016). However, Late Bronze Age Cyprus cannot be understood out of its Eastern Mediterranean context, and not only commodities and objects, but also people, and with them, ideas, perceptions, and traditions travelled and may have spread over vast areas. The complexity of cultural transformations caused by highly interconnected regions and human mobility (e.g., Clarke 2005) is not easy to elucidate. At the same time, not all external influences are integrated equally in all aspects of life. While ritual, religion, and cult have often a priori been considered as conservative aspects of culture and behaviour (cf. the discussion in Whitley 2009), they may dynamically adopt and adapt foreign objects, symbols, practices, and beliefs (see, e.g., most recently Papadopoulos 2020). Along these lines, Louise Steel (2010) has highlighted the varying popularity of Cypriot finewares throughout the Late Bronze Age and pointed out that funerary and ritual contexts may be particularly open to changes.

As regards the material culture, the integration of the Mycenaean drinking set-albeit with modifications-is the most obvious component in many ritual assemblages (van Wijngaarden 2002, pp. 125-202). In Area A of Hala Sultan Tekke piriform jars, especially those of small and medium size are particularly common in comparison to similar contexts in Greece (e.g., Walberg 2007), whereas open shapes such as kylikes and bowls which are a common part of the Mycenaean eating/drinking set are relatively rare. In fact, small piriform jars were the first Mycenaean (LH IIIA1 and IIIA2) shape to be imitated by local potters already in the early 14th century BCE (Graziadio 2017). Consequently, this vessel type was not only imported as a container for precious substances but must have played an important role in Late Cypriot practices of consumption, especially in ritual and mortuary contexts. In contrast to bowls, kraters, jugs, and juglets, the piriform jar does not exist in the local repertoire of shapes (with the exception of the local production of the Mycenaean type pointed out above).

The scarcity of imported open shapes may also be explained by conservatism in specific aspects of cult, analogous to the evidence from the Sanctuary of the Ingot God in Enkomi, where the local eating and drinking vessels were preferred. The krater, as important or even the 'centerpiece of the LC drinking set' (Steel 2004, p. 293) is unevenly distributed in the contexts of Hala Sultan Tekke, Area A. While it is well represented in the deposits of Tomb SS but also in Pits V and GG, it does not occur in Well F or in the 'offering 
pits' Pit B, Z6 and Z7. Numerous previous studies have pointed out the production of Mycenaean (amphoroid) kraters, often with pictorial decoration, specifically for the Cypriot market (e.g., Morris 1989, pp. 207-14; van Wijngaarden 2002, p. 276; Jung 2015), which again proves a high selectivity by Cypriot consumers in adopting and integrating items from overseas into local practices. These kraters are almost exclusively found in ritual and especially in mortuary contexts and seem to correlate with high prestige goods such as bronze vessels, weapons, and gold jewelry (Keswani 2004, pp. 129-39, 241-45, Table 5.11) and consequently served as funerary display of the highest social groups.

Anatolian Red Lustrous Wheel-made ware occurs comparatively rarely, and the predominant shape is the spindle bottle which due to its limited capacity most likely was imported as container of precious liquid items. In contrast, large shallow bowls, lentoid flasks and kraters are rare and these vessels do not seem to have played a crucial role in ritual consumption as the Mycenaean imports did. Cypriot White Shaved juglets as well as Anatolian produced copies were, vice versa, integrated in local cultic practice in Anatolia and at Alalakh (Akar 2017). This type of vessel has its origin in the Levantine dipper juglets already known in the Middle Bronze Age, hence showing a pattern of connectivity between Cyprus, the Levant, Cilicia and central Anatolia from the 16th century on, and particularly in the 15th and 14th centuries BCE (Akar 2017, pp. 11-12). Interestingly, this spread corresponds well with that of the Red Lustrous Wheel-made ware (Akar 2017, p. 12; see also Kozal).

A limited role in ritual consumption may, however, apply to imported pottery from the Levant, which mainly comprises transport jars, since these are, with the exception of Tomb SS, not commonly found in mortuary and ritual contexts; even less common are Levantine lentoid flasks (see though one from Hala Sultan Tekke Tomb X in Bürge 2017, p. 192, Figure 27). Other Levantine influences are, e.g., expressed in the ashlar-built tombs of Enkomi and in specific Tomb 66, where, as reconstructed by Lindy Crewe (2009), lamps and a silver bowl were suspended from bronze pins in the wall by the door of the tomb. Crewe suggested that a Near Eastern and Levantine style kispum ritual of feasting or drinking with the deceased may have taken place in the tomb, i.e., as an emulation of these practices by the local élites (Crewe 2009). Similarly, in comparing mortuary practices at Enkomi and Ugarit, Keswani (2012b) has argued that a similar set of prestige symbolism was shared by the élites of the two policies during their heyday, i.e., in the 14th and 13th centuries BCE. Not only may the Cypriots have emulated prestigious Levantine mortuary practices, also human mobility in the form of intermarriage or long-distance trade may have influenced ritual practices in both directions. Towards the end of the 13th century BCE, however, the mortuary expenditure in Enkomi declined hand in hand with other societal changes (see above), perhaps indicating the diminished importance of kin group identity, whereas in Ugarit we see an increased elaboration of ashlar tombs, which points to continued power and competition of élites (Keswani 2012b, p. 199).

The role of the Sardinian bowls and the large fragment of a (cooking?) pot (Bürge and Fischer 2020; Gradoli et al. 2020) in the 'offering pits' Pit B, Z6 and Z7 is particularly interesting, since besides these only a few Sardinian vessels, all of them jars, have been found or were identified on Cyprus, i.e., at Pyla Kokkinokremos (Bretschneider et al. 2017), roughly $17 \mathrm{~km}$ east of Hala Sultan Tekke. The pits of Hala Sultan Tekke are the only context where these small, shallow bowls have been found so far. Their small capacity of ca. 0.05-0.15l makes them unsuitable for the consumption of large amounts of food or liquid. They may have rather been used for libation or 'symbolic consumption'. The meaning of the Sardinian (cooking?) pot in this specific context is even more difficult to assess, in particular since not the entire vessel but only a large fragment was deposited. However, the fact that these objects were integrated in the local Cypriot cultic practice-perhaps with a specific meaning or with the awareness of them being exotic items-is striking and once again testifies to the high level of connectivity and receptivity of the Late Cypriot society to external influences. 


\section{Conclusions and Outlook}

Evi Gorogianni's (2020) notion that 'the Aegean of the MBA and the LBA bears almost all the hallmarks of an ancient globalization' (with references to Jennings 2011, pp. 20-32; 2017; Hodos 2017) may also apply to Late Bronze Age Cyprus. The highly intertwined cultic landscape of Late Cypriot cemeteries nevertheless shows some very specific Cypriot characteristics. While it cannot be excluded that some peculiarities might be limited to Hala Sultan Tekke, the cursory review of other sites has shown that at least some island-wide commonalities existed. As Broodbank (2000, p. 363) stated, 'insularity is [ ... ] a dynamic condition', it is not only dynamic across time but also regarding specific aspects of daily life, ritual and religious practice, specific areas and realms, as well as social groups, individuals, and expressions of identity. It is always difficult to assess whether, or to what degree, the society, social groups, and individuals felt aware of connectivity (or insularity).

Nevertheless, the Late Cypriot evidence clearly points to a high awareness of this connectivity based on the important role of economic connections with the surrounding cultures. The use of exotic materials and imported objects of high value in rituals and the emulation of Levantine (and perhaps other foreign) practices certainly also served to establish and negotiate authority and to display wealth and power by the emerging élites at the beginning of and during the Late Cypriot period (Webb 2014). In a nutshell, the Late Cypriot culture and society can to a high extent be characterised by extra-insular contacts and interactions and insularity should not simply be regarded as geographical condition, it rather symbolises the way island societies deal with the presence of the sea (Robb 2001, pp. 195-96; see also Knapp 2008, p. 25). Besides the integration, appropriation, and adaptation of foreign items into local cultic practices, the contexts from Hala Sultan Tekke, which represent the largest known Late Cypriot assemblage of fish and other marine animals, attest to the important role that coastal and maritime resources may have played in various aspects of mundane and ritual life. In summary, due to the complex ritual and mortuary evidence of Late Bronze Age Cyprus only a brief overview of the main aspects related to the function and use of cemeteries as space for various mortuary rituals, feasting, and commemoration could be provided. Forthcoming studies will focus particularly on detailed analyses of structured depositions throughout the entire island, possible diachronic changes, exact functions, uses, and mechanisms of adoption and adaptation of imported objects as well as on other dynamics of cultural transformation reflected in ritual and cult of the island.

Funding: This research was funded by an APART-GSK fellowship of the Austrian Academy of Sciences, grant number 11861.

Data Availability Statement: Not applicable.

Acknowledgments: I would like to thank Peter M. Fischer, the director of the excavations at Hala Sultan Tekke, for giving me access to the material from Area A and for allowing me to publish it. I am also grateful to the editors of the special issue and to the three anonymous reviewers for their comments, suggestions and corrections.

Conflicts of Interest: The author declares no conflict of interest.

\section{References}

Akar, Murat. 2017. Pointed Juglets as an International Trend in Late Bronze Ritual Practices: A View from Alalakh. In Overturning Certainties in Near Eastern Archaeology. A Festschrift in Honor of K. Aslihan Yener. Edited by Çiğdem Maner, Mara T. Horowitz and Allan S. Gilbert. Culture and History of the Ancient Near East 90. Leiden and Boston: Brill, pp. 1-24.

Alexandrou, Constantina. 2019. Late Cypriot Female Figurines: From Intra- to Inter-site Investigation of Their Function and Life-cycle. In Unlocking Sacred Landscapes: Spatial Analysis of Ritual and Cult in the Mediterranean. Edited by Giorgos Papantoniou, Christine E. Morris and Athanasios K. Vionis. Studies in Mediterranean Archaeology 151. Nicosia: Åström, pp. 201-18.

Aruz, Joan, Sarah B. Graff, and Yelena Rakic, eds. 2013. Cultures in Contact: From Mesopotamia to the Mediterranean in the Second Millennium B.C. New Haven: Yale University Press.

Åström, Paul. 1983. Chamber Tombs. In Hala Sultan Tekke 8: Excavations 1971-1979. Edited by Paul Åström, Elisabeth Åström, Anna Hatziantoniou, Karin Niklasson and Ulla Öbrink. Studies in Mediterranean Archaeology 45:8. Göteborg: Åström, pp. 145-68. 
Åström, Paul. 1998. Hala Sultan Tekke 10. The Wells. Studies in Mediterranean Archaeology 45:10. Jonsered: Åström.

Åström, Paul, and Emilia Masson. 1982. A Silver Bowl with Canaanite Inscription from Hala Sultan Tekké. Report of the Department of Antiquities, Cyprus, 73-76.

Åström, Paul, and Karin Nys. 2007. Tomb 24. In Hala Sultan Tekke 12: Tomb 24, Stone Anchors, Faunal Remains and Pottery Provenance. Edited by Paul Åström and Karin Nys. Studies in Mediterranean Archaeology 45:12. Sävedalen: Åström, pp. 6-30.

Bader, Bettina. 2010. Processing and Analysis of Ceramic Finds at the Egyptian Site of Tell el-Dabca/Avaris ("Eves" and Other Strange Animals). In Analysing Pottery: Processing, Classification, Publication. Edited by Barbara Horejs, Reinhard Jung and Peter Pavúk. Facultas Philosophica Universitatis Comenianae Bratislavensis, Studia Archaeologica et Medievalia 10. Bratislava: Comenius University in Bratislava, pp. 209-33.

Bailey, Donald M. 1976. The British Museum Excavations at Hala Sultan Tekke in 1897 and 1898: The Material in the British Museum. In Hala Sultan Tekke 1: Excavations 1897-1971. Edited by Paul Åström, Donald M. Bailey and Vassos Karageorghis. Studies in Mediterranean Archaeology 45:1. Göteborg: Åström, pp. 1-32.

Bar-Yosef Mayer, Daniella E., Yaacov Kahanov, Joel Roskin, and Hezi Gildor. 2015. Neolithic Voyages to Cyprus: Wind Patterns, Routes, and Mechanisms. The Journal of Island and Coastal Archaeology 10: 412-35. [CrossRef]

Bretschneider, Joachim, Athanasia Kanta, and Jan Driessen. 2017. Pyla-Kokkinokremos (Cyprus): Preliminary Report on the 2015-2016 Campaigns. Ugarit-Forschungen: Internationales Jahrbuch für die Altertumskunde Syrien-Palästinas 47: 35-120.

Broodbank, Cyprian. 2000. An Island Archaeology of the Early Cyclades. Cambridge: Cambridge University Press.

Brubaker, Rogers, and Frederick Cooper. 2000. Beyond 'Identity'. Theory and Society 29: 1-47. [CrossRef]

Budin, Stephanie L. 2009. Girl, Woman, Mother, Goddess: Bronze Age Cypriot Terracotta Figurines. Medelhavsmuseet: Focus on the Mediterranean 5: 76-88.

Bürge, Teresa. 2017. Ritual Depositions versus Garbage Pits: A Re-evaluation of Pottery Deposits and Offering Pits at the Late Bronze Age City of Hala Sultan Tekke, Cyprus. Egypt and the Levant 27: 133-50. [CrossRef]

Bürge, Teresa, and Peter M. Fischer. 2017. New Insights on Burial Practices at the Late Bronze Age City of Hala Sultan Tekke, Cyprus. Ugarit-Forschungen: Internationales Jahrbuch für die Altertumskunde Syrien-Palästinas 48: 121-71.

Bürge, Teresa, and Peter M. Fischer. 2018. The Pottery. In Two Late Cypriot City Quarters at Hala Sultan Tekke: The Söderberg Expedition 2010-2017. Edited by Peter M. Fischer and Teresa Bürge. Studies in Mediterranean Archaeology 147. Uppsala: Åström, pp. $187-416$.

Bürge, Teresa, and Peter M. Fischer. 2020. Nuragic Pottery from Hala Sultan Tekke: The Cypriot-Sardinian Connection. Egypt and the Levant 29: 231-44. [CrossRef]

Caloi, Ilaria. 2011. Minoan Inverted Vases in Funerary Contexts: Offerings to Dead or to Ancestors? Annuario della Scuola Archeologica Italiana di Atene 89: 135-46.

Charles, Douglas K., and Jane E. Buikstra. 2002. Siting, Sighting, and Citing the Dead. In The Space and Place of Death. Edited by Helaine Silverman and David B. Small. Archaeological Papers of the American Anthropological Association 11. Arlington: The American Anthropological Association, pp. 13-25.

Clarke, Joanne. 2005. Cultural Transmissions and Transformations. In Archaeological Perspectives on the Transmission and Transformation of Culture in the Eastern Mediterranean. Edited by Joanne Clarke. Levant Supplementary Series 2; Oxford: Oxbow, pp. 1-6.

Collins, Billie Jean. 2002. Necromancy, Fertility and the Dark Earth: The Use of Ritual Pits in Hittite Cult. In Magic and Ritual in the Ancient World. Edited by Paul Allan Mirecki and Marvin W. Meyer. Religions in the Graeco-Roman World 141. Leiden and Boston: Brill, pp. 224-41.

Crewe, Lindy. 2009. Feasting with the Dead? Tomb 66 at Enkomi. In Ancient Cyprus in the British Museum: Essays in Honour of Veronica Tatton-Brown. Edited by Thomas Kiely. British Museum Research Publication 180. London: British Museum Press, pp. $27-48$.

Dakouri-Hild, Anastasia, and Michael J. Boyd, eds. 2016. Staging Death: Funerary Performance, Architecture and Landscape in the Aegean. Berlin and Boston: De Gruyter.

Devillers, Benoît, Michael Brown, and Christophe Morhange. 2015. Paleo-environmental Evolution of the Larnaca Salt Lakes (Cyprus) and the Relationship to Second Millennium BC Settlement. Journal of Archaeological Science: Reports 1: 73-80. [CrossRef]

Dietler, Michael. 2001. Theorizing the Feast: Rituals of Consumption, Commensal Politics, and Power in African Contexts. In Feasts: Archaeological and Ethnographic Perspectives on Food, Politics, and Power. Edited by Michael Dietler and Brian Hayden. Washington, DC: Smithsonian Institute Press, pp. 65-114.

Dikaios, Porphyrios. 1969. Enkomi. Excavations 1948-1958. Volume I: The Architectural Remains, the Tombs. Mainz am Rhein: Von Zabern.

Duistermaat, Kim, and Ilona Regulski, eds. 2011. Intercultural Contacts in the Ancient Mediterranean: Proceedings of the International Conference at the Netherlands-Flemish Institute in Cairo, 25th to 29th October 2008. Orientalia Lovaniensia Analecta 202. Leuven: Peeters.

Eder, Birgitta, and Regine Pruzsinszky, eds. 2015. Policies of Exchange: Political Systems and Modes of Interaction in the Aegean and the Near East in the 2nd Millennium B.C.E. Proceedings of the International Symposium at the University of Freiburg, Institute for Archaeological Studies, 30th May_-2nd June 2012. Oriental and European Archaeology 2. Vienna: Austrian Academy of Sciences.

Ekroth, Gunnel. 2017. “Don't Throw Any Bones in the Sanctuary!” On the Handling of Sacred Waste at Ancient Greek Cult Places. In Ritual Matters: Material Residues and Ancient Religions. Edited by Claudia Moser and Jennifer W. Knust. Memoirs of the American Academy in Rome Supplement 13. Ann Arbor: University of Michigan Press, pp. 33-55. 
Eriksson, Kathryn O. 2008. Feasting as Part of the Multiculturalism of Late Bronze Age Cyprus. In DAIS-The Aegean Feast. Proceedings of the 12th International Aegean Conference/University of Melbourne, Centre for Classics and Archaeology, 25-29 March 2008. Edited by Louise A. Hitchcock, Robert Laffineur and Janice L. Crowley. Aegaeum 29. Liège: Université de Liège, pp. $297-307$.

Fischer, Peter M. 2020. The Occupational History of the Bronze Age Harbour City of Hala Sultan Tekke, Cyprus. Egypt and the Levant 29: 189-230. [CrossRef]

Fischer, Peter M., and Teresa Bürge. 2015. The New Swedish Cyprus Expedition 2014: Excavations at Hala Sultan Tekke. Preliminary Results. Opuscula. Annual of the Swedish Institutes at Athens and Rome 8: 27-79. [CrossRef]

Fischer, Peter M., and Teresa Bürge. 2016. The New Swedish Cyprus Expedition 2015: Excavations at Hala Sultan Tekke. Preliminary Results. Opuscula. Annual of the Swedish Institutes at Athens and Rome 9: 33-58. [CrossRef]

Fischer, Peter M., and Teresa Bürge. 2017. Tombs and Offering Pits at the Late Bronze Age Metropolis of Hala Sultan Tekke, Cyprus. Bulletin of the American Schools of Oriental Research 377: 161-218. [CrossRef]

Fischer, Peter M., and Teresa Bürge. 2018a. Stratigraphy, Architecture and Finds. In Two Late Cypriot City Quarters at Hala Sultan Tekke: The Söderberg Expedition 2010-2017. Edited by Peter M. Fischer and Teresa Bürge. Studies in Mediterranean Archaeology 147. Uppsala: Åström, pp. 17-186.

Fischer, Peter M., and Teresa Bürge. 2018b. The New Swedish Cyprus Expedition 2017: Excavations at Hala Sultan Tekke (The Söderberg Expedition). Preliminary Results. Opuscula. Annual of the Swedish Institutes at Athens and Rome 11: 29-79. [CrossRef]

Fischer, Peter M., and Teresa Bürge. 2020. The New Swedish Cyprus Expedition 2019: Excavations at Hala Sultan Tekke (The Söderberg Expedition): Preliminary Results. Opuscula. Annual of the Swedish Institutes at Athens and Rome 13: 73-111. [CrossRef]

Fischer, Peter M., and Teresa Bürge. in press a. The New Swedish Cyprus Expedition 2020 (The Söderberg Expedition): Excavations in the Cemetery of Hala Sultan Tekke. Egypt and the Levant 31.

Fischer, Peter M., and Teresa Bürge. in press b. The New Swedish Cyprus Expeditions 2020 and 2021: Excavations at Hala Sultan Tekke (The Söderberg Expedition): Preliminary Results. Opuscula. Annual of the Swedish Institutes at Athens and Rome 15.

Fischer, Peter M., and Teresa Bürge, eds. in press c. The Decline of Bronze Age Civilisations in the Mediterranean: Cyprus and Beyond: Proceedings of a Conference Held in Gothenburg, 17-18 January 2020. Studies in Mediterranean Archaeology. Nicosia: Åström.

Georgiou, Artemis. 2019. Tracing the Foundation Horizon of Palaepaphos: New Research on the Early History of the Paphos Region. In New Directions in Cypriot Archaeology. Edited by Catherine Kearns and Sturt W. Manning. Ithaca: Cornell University Press, pp. 190-218.

Gilmour, Garth H. 1997. The Nature and Function of Astragalus Bones from Archaeological Contexts in the Levant and Eastern Mediterranean. Oxford Journal of Archaeology 16: 167-75. [CrossRef]

Gjerstad, Einar, John Lindros, Erik Sjöqvist, and Alfred Westholm. 1934. Finds and Results of the Excavations in Cyprus 1927-1931. The Swedish Cyprus Expedition 1. Stockholm: The Swedish Cyprus Expedition.

Gordon, Jody Michael, and Anna Kouremenos. 2020. Introduction. In Mediterranean Archaeologies of Insularity in an Age of Globalization. Edited by Anna Kouremenos and Jody Michael Gordon. Oxford and Philadelphia: Oxbow Books, pp. 1-26.

Gorogianni, Evi. 2020. Mobility and Globalization: The View from the Bronze Age Cyclades. In Mediterranean Archaeologies of Insularity in an Age of Globalization. Edited by Anna Kouremenos and Jody Michael Gordon. Oxford and Philadelphia: Oxbow Books, pp. 53-88.

Gradoli, Maria Giuseppina, Paula Waiman-Barak, Teresa Bürge, Zachary C. Dunseth, Johannes H. Sterba, Fulvia Lo Schiavo, Mauro Perra, Serena Sabatini, and Peter M. Fischer. 2020. Cyprus and Sardinia in the Late Bronze Age: Nuragic Table Ware at Hala Sultan Tekke. Journal of Archaeological Science: Reports 33: 102479. [CrossRef]

Graziadio, Giampaolo. 2017. The Earliest Production of Aegean-Type Pottery in Cyprus. Pisa: Pisa University Press.

Hamilakis, Yannis. 1998. Eating the Dead: Mortuary Feasting and the Politics of Memory in the Aegean Bronze Age Societies. In Cemetery and Society in the Aegean Bronze Age. Round Table Held in Sheffield, November 29th—December 1st, 1996. Edited by Keith Branigan. Sheffield: Sheffield Academic Press, pp. 115-32.

Hamilakis, Yannis. 2008. Time, Performance, and the Production of a Mnemonic Record: From Feasting to an Archaeology of Eating and Drinking. In DAIS-The Aegean Feast. Proceedings of the 12th International Aegean Conference/University of Melbourne, Centre for Classics and Archaeology, 25-29 March 2008. Edited by Louise A. Hitchcock, Robert Laffineur and Janice L Crowley. Aegaeum 29. Liège: Université de Liège, pp. 3-18.

Hayden, Brian. 2009. Funerals as Feasts: Why Are They so Important? Cambridge Archaeological Journal 19: 29-52. [CrossRef]

Hodos, Tamar. 2017. Globalization: Some Basics: An Introduction to The Routledge Handbook of Archaeology and Globalization. In The Routledge Handbook of Archaeology and Globalization. Edited by Tamar Hodos. London and New York: Routledge, pp. 3-11.

Horden, Peregrine, and Nicholas Purcell. 2000. The Corrupting Sea: A Study of Mediterranean History. Oxford: Blackwell.

Iacovou, Maria. 2008. "The Palaepaphos Urban Landscape Project": Theoretical Background and Preliminary Report 2006-2007. Report of the Department of Antiquities, Cyprus, 263-90.

Jennings, Justin. 2011. Globalizations and the Ancient World. New York: Cambridge University Press.

Jennings, Justin. 2017. Distinguishing Past Globalizations. In The Routledge Handbook of Archaeology and Globalization. Edited by Tamar Hodos. London and New York: Routledge, pp. 12-28. 
Jung, Reinhard. 2011. Tafeln in Enkomi vom 13. bis zum 12. Jh. v. u. Z.: Neue Töpfe auf dem Tisch oder neue Gäste am Tisch? In Österreichische Forschungen zur Ägäischen Bronzezeit 2009. Akten der Tagung vom 6. bis 7. März 2009 am Fachbereich Altertumswissenschaften der Universität Salzburg. Edited by Fritz Blakolmer, Claus Reinholdt, Jörg Weilhartner and Georg Nightingale. Vienna: Phoibos, pp. 173-95.

Jung, Reinhard. 2015. Imported Mycenaean Pottery in the East: Distribution, Context and Interpretation. In Policies of Exchange: Political Systems and Modes of Interaction in the Aegean and the Near East in the 2nd Millennium B.C.E. Proceedings of the International Symposium at the University of Freiburg, Institute for Archaeological Studies, 30th May-2nd June 2012. Edited by Birgitta Eder and Regine Pruzsinszky. Oriental and European Archaeology 2. Vienna: Austrian Academy of Sciences, pp. $243-75$.

Karageorghis, Vassos. 1965. Nouveaux Documents Pour L'étude du Bronze Récent à Chypre. Études Chypriotes 3. Paris: De Boccard.

Karageorghis, Vassos. 1976. Two Late Bronze Age Tombs from Hala Sultan Tekke. In Hala Sultan Tekke 1: Excavations 1897-1971. Edited by Paul Åström, Donald M. Bailey and Vassos Karageorghis. Studies in Mediterranean Archaeology 45:1. Göteborg: Åström, pp. 71-89.

Karageorghis, Vassos. 1983. Chronique des fouilles et découvertes archéologiques à Chypre en 1982. Bulletin de Correspondance Hellénique 107: 905-53.

Karageorghis, Vassos. 1990. Miscellanea from Late Bronze Age Cyprus II: A Late Bronze Age Musical Instrument? Levant 22: 159. [CrossRef]

Karageorghis, Vassos. 2016. The "Royal" Tombs of Salamis on Cyprus. In Assyria to Iberia: Art and Culture in the Iron Age. Edited by Joan Aruz and Michael Seymour. New York, New Haven and London: The Metropolitan Museum of Art, pp. 188-92.

Karageorghis, Vassos, and Efstathios Raptou. 2016. Palaepaphos-Skales: Tombs of the Late Cypriote IIIB and Cypro-Geometric Periods (Excavations of 2008 and 2011). Nicosia: The Cyprus Institute.

Karageorghis, Vassos, and Efstathios Raptou. 2019. Palaepaphos-Skales Tomb 277. More Prestigious Burials. Opuscula. Annual of the Swedish Institutes at Athens and Rome 12: 327-67. [CrossRef]

Kelly, John D., and Martha Kaplan. 1990. History, Structure, and Ritual. Annual Review of Anthropology 19: 119-50. [CrossRef]

Keswani, Priscilla S. 1989. Dimensions of Social Hierarchy in Late Bronze Age Cyprus: An Analysis of the Mortuary Data from Enkomi. Journal of Mediterranean Archaeology 2: 49-86. [CrossRef]

Keswani, Priscilla S. 2004. Mortuary Ritual and Society in Bronze Age Cyprus. Monographs in Mediterranean Archaeology 9. London: Equinox.

Keswani, Priscilla S. 2012a. Mortuary Practices and Burial Cults in Cyprus from the Bronze Age through the Early Iron Age. In Parallel Lives: Ancient Island Societies in Crete and Cyprus. Papers Arising from the Conference in Nicosia Organised by the British School at Athens, the University of Crete and the University of Cyprus, in November-December 2006. Edited by Gerald Cadogan, Maria Iacovou, Katerina Kopaka and James Whitley. British School at Athens Studies 20. London: British School at Athens, pp. 313-30.

Keswani, Priscilla S. 2012b. Urban Mortuary Practices at Enkomi and Ugarit in the Second Millennium BC. In (Re-)Constructing Funerary Rituals in the Ancient Near East. Proceedings of the First International Symposium of the Tübingen Post-Graduate School "Symbols of the Dead" in May 2009. Edited by Peter Pfälzner, Herbert Nier, Ernst Pernicka and Anne Wissing. Qatna Studien: Supplementa 1. Wiesbaden: Harrassowitz, pp. 183-203.

Kibaroğlu, Mustafa, Ekin Kozal, Andreas Klügel, Gerald Hartmann, and Patrick Monien. 2019. New Evidence on the Provenance of Red Lustrous Wheel-made Ware (RLW): Petrographic, Elemental and Sr-Nd Isotope Analysis. Journal of Archaeological Science: Reports 24: 412-33. [CrossRef]

Knapp, A. Bernard. 1986. Production, Exchange, and Socio-political Complexity on Bronze Age Cyprus. Oxford Journal of Archaeology 5: 35-60. [CrossRef]

Knapp, A. Bernard. 2007. Insularity and Island Identity in the Prehistoric Mediterranean. In Mediterranean Crossroads. Edited by Sophia Antoniadou and Anthony Pace. Athens: Pierides Foundation, pp. 37-62.

Knapp, A. Bernard. 2008. Prehistoric and Protohistoric Cyprus: Identity, Insularity and Connectivity. Oxford: Oxford University Press.

Knapp, A. Bernard. 2020. Maritime Narratives of Prehistoric Cyprus: Seafaring as Everyday Practice. Journal of Maritime Archaeology 15: 415-50. [CrossRef]

Knapp, A. Bernard, and Peter van Dommelen, eds. 2014. The Cambridge Prehistory of the Bronze and Iron Age Mediterranean. Cambridge: Cambridge University Press.

Kozal, Ekin. in press. Cypro-Anatolian Connections en route to the Downfall of the Late Bronze Age: An Archaeological Perspective. In The Decline of Bronze Age Civilisations in the Mediterranean: Cyprus and Beyond. Edited by Peter M. Fischer and Teresa Bürge. Studies in Mediterranean Archaeology. Nicosia: Åström.

Lagarce, Jacques. 1986. L'alimentation en eau: Les puits et leur contenu archéologique. In Enkomi et le Bronze Récent à Chypre. Edited by Jacques-Claude Courtois, Jacques Lagarce and Elisabeth Lagarce. Nicosia: A.G. Leventis Foundation, pp. 56-58.

Morhange, Christophe, Jean-Philippe Goiran, Michel Bourcier, Pierre Carbonel, Joël Le Campion, Jean-Marie Rouchy, and Marguerite Yon. 2000. Recent Holocene Paleo-environmental Evolution and Coastline Changes of Kition, Larnaca, Cyprus, Mediterranean Sea. Marine Geology 170: 205-30. [CrossRef]

Morley, Iain. 2005. The Long-Forgotten Melody? Music in the Mesolithic. In Mesolithic Studies at the Beginning of the 21st Century. Edited by Nicky Milner and Peter Woodman. Oxford: Oxbow Books, pp. 212-25.

Morris, Christine E. 1989. The Mycenaean Amphoroid Krater: A Study in Form, Design and Function. Ph.D. thesis, University College London, London, UK. 
Morris, Ian. 1991. The Archaeology of Ancestors: The Saxe/Goldstein Hypothesis Revisited. Cambridge Archaeological Journal 1: 147-69. [CrossRef]

Niklasson, Karin. 1983. Tomb 23: A Shaft-Grave of the Late Cypriote III Period. In Hala Sultan Tekke 8: Excavations 1971-1979. Edited by Paul Åström, Elisabeth Åström, Anna Hatziantoniou, Karin Niklasson and Ulla Öbrink. Studies in Mediterranean Archaeology 45:8. Göteborg: Åström, pp. 169-213.

Öbrink, Ulla. 1979. Hala Sultan Tekke 6. A Sherd Deposit in Area 22. Studies in Mediterranean Archaeology 45:6. Göteborg: Åström.

Öbrink, Ulla. 1983. A Well of the Early 14th Century BC. In Hala Sultan Tekke 8: Excavations 1971-1979. Edited by Paul Åström, Elisabeth Åström, Anna Hatziantoniou, Karin Niklasson and Ulla Öbrink. Studies in Mediterranean Archaeology 45:8. Göteborg: Åström, pp. 16-58.

Papadopoulos, Angelos. 2020. Deconstructing the Image of the Warrior. In Communication Uneven: Acceptance of and Resistance to Foreign Influences in the Connected Ancient Mediterranean. Edited by Jan Driessen and Alessandro Vanzetti. AEGIS 20. Louvain-La-Neuve: Presses Universitaires, pp. 171-88.

Papasavvas, George. 2014. Feasting, Deposition and Abandonment in the Sanctuary of the Horned God at Enkomi. In Structure, Measurement and Meaning. Studies on Prehistoric Cyprus in Honour of David Frankel. Edited by Jennifer M. Webb. Studies in Mediterranean Archaeology 143. Åström: Uppsala, pp. 245-60.

Pfälzner, Peter, Herbert Nier, Ernst Pernicka, and Anne Wissing, eds. 2012. (Re-)Constructing Funerary Rituals in the Ancient Near East: Proceedings of the First International Symposium of the Tübingen Post-Graduate School "Symbols of the Dead" in May 2009. Qața Studien: Supplementa 1. Wiesbaden: Harrassowitz.

Quilici, Lorenzo. 1991. La tomba dell'età del Bronzo Tardo dall'abitato di Paleokastro presso Ayia Irini. Biblioteca di Antichità Cipriote 6. Rome: Istituto per gli Studi Micenei ed Egeo Anatolici del CNR.

Reese, David S. 1998. Appendix II: Fauna from Late Cypriote Wells and Pits. In Hala Sultan Tekke 10. The Wells. Edited by Paul Åström. Studies in Mediterranean Archaeology 45:10. Jonsered: Åström, pp. 136-39.

Reese, David S. 2002. On the Incised Cattle Scapulae from the East Mediterranean and Near East. Bonner Zoologische Beiträge 50: 183-98.

Robb, John. 2001. Island Identities: Ritual, Travel and the Creation of Difference in Neolithic Malta. European Journal of Archaeology 4: 175-202. [CrossRef]

Safadi, Crystal. 2016. Wind and Wave Modelling for the Evaluation of the Maritime Accessibility and Protection Afforded by Ancient Harbours. Journal of Archaeological Science: Reports 5: 348-60. [CrossRef]

Safadi, Crystal, and Fraser Sturt. 2019. The Warped Sea of Sailing: Maritime Topographies of Space and Time for the Bronze Age Eastern Mediterranean. Journal of Archaeological Science 103: 1-15. [CrossRef]

Samaes, Melissa, and Karin Nys. 2010. T.1 MLA 1173, An Extra Urban Tomb of the Late Bronze Age Site near Hala Sultan Tekke. Report of the Department of Antiquities, Cyprus, 199-228.

Silverman, Helaine. 2002. Introduction: The Space and Place of Death. In The Space and Place of Death. Edited by Helaine Silverman and David B. Small. Archaeological Papers of the American Anthropological Association 11. Arlington: The American Anthropological Association, pp. 1-11.

South, Alison K. 2008. Feasting in Cyprus. A View from Kalavasos. In DAIS-The Aegean Feast. Proceedings of the 12th International Aegean Conference/University of Melbourne, Centre for Classics and Archaeology, 25-29 March 2008. Edited by Louise A. Hitchcock, Robert Laffineur and Janice L. Crowley. Aegaeum 29. Liège: Université de Liège, pp. 309-15.

Steel, Louise. 2004. A Goodly Feast ... A Cup of Mellow Wine: Feasting in Bronze Age Cyprus. In The Mycenaean Feast. Edited by James C. Wright. Hesperia 73:2. Princeton: American School of Classical Studies at Athens, pp. 281-300.

Steel, Louise. 2010. Late Cypriot Ceramic Production. Heterarchy or Hierarchy? In Development of Pre-State Communities in the Ancient Near East. Edited by Diane Bolger and Louise C. Maguire. Oxford: Oxbow Books, pp. 106-16.

Steel, Louise. 2021. Inscribing Bodies in Bronze Age Cyprus. In The Sacred Body. Materializing the Divine through Human Remains in Antiquity. Edited by Nicola Laneri. Material Religion in Antiquity 1. Oxford: Oxbow Books, pp. 29-44.

Sterba, Johannes H. in press. Neutron Activation Analysis of the Pottery Corpus of Hala Sultan Tekke and Comparison to Literature Data. In The Decline of Bronze Age Civilisations in the Mediterranean: Cyprus and Beyond: Proceedings of a Conference Held in Gothenburg, 17-18 January 2020. Edited by Peter M. Fischer and Teresa Bürge. Studies in Mediterranean Archaeology. Nicosia: Åström.

Stieglitz, Robert R. 1984. The Ugaritic Inscription from Hala Sultan Tekke. Opuscula Atheniensia 15: 193.

Stolle, Bettina. 2016. The Reuse of a Well as a Deposit for Seven Individuals at Hala Sultan Tekke. In Ancient Cyprus Today. Museum Collections and New Research. Edited by Giorgos Bourogiannis and Christian Mühlenbock. Studies in Mediterranean Archaeology and Literature: Pocket-book 184. Uppsala: Åström, pp. 219-28.

van Wijngaarden, Gert Jan. 2002. Use and Appreciation of Mycenaean Pottery in the Levant, Cyprus and Italy (1600-1200 BC). Archaeological Studies 8. Amsterdam: Amsterdam University Press.

Vermeule, Emily D. T., and Florence Z. Wolsky. 1990. Toumba tou Skourou: A Bronze Age Potters' Quarter on Morphou Bay in Cyprus. Cambridge: Harvard University Press.

von Rüden, Constance. 2016. Concluding Remarks: Feasting, Craft and Depositional Practice in Late Bronze Age Palaepaphos. In Feasting, Craft and Depositional Practice in Late Bronze Age Palaepaphos: The Well Fillings of Evreti. Edited by Constance von Rüden, Artemis Georgiou, Ariane Jacobs and Paul Halstead. Bochumer Forschungen Zur Ur- und Frühgeschichtlichen Archäologie 8. Rahden: Marie Leidorf, pp. 419-25. 
Walberg, Gisela, ed. 2007. Midea: The Megaron Complex and Shrine Area: Excavations on the Lower Terraces 1994-1997. Prehistory Monographs 20. Philadelphia: INSTAP Academic Press.

Webb, Jennifer M. 1985. The Incised Scapulae. In Excavations at Kition V. The Pre-Phoenician Levels. Part II. Edited by Vassos Karageorghis. Nicosia: Department of Antiquities, pp. 317-28.

Webb, Jennifer M. 1992. Funerary Ideology in Bronze Age Cyprus. Toward the Recognition and Analysis of Cypriote Ritual Data.

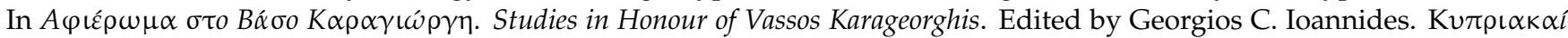
$\Sigma \pi \mathrm{ov} \delta \alpha i$ 54/55. Nicosia: Society of Cypriot Studies, pp. 87-99.

Webb, Jennifer M. 1999. Ritual Architecture, Iconography and Practice in the Late Cypriot Bronze Age. Studies in Mediterranean Archaeology and Literature: Pocket-Book 75. Jonsered: Åström.

Webb, Jennifer M. 2014. Ritual as the Setting for Contentious Interaction: From Social Negotiation to Institutionalised Authority in Bronze Age Cyprus. In The Cambridge Prehistory of the Bronze and Iron Age Mediterranean. Edited by A. Bernard Knapp and Peter van Dommelen. Cambridge: Cambridge University Press, pp. 619-34.

Webb, Jennifer M. 2018. Spatial and Social Discontinuities in Burial Practice and the Privatisation of Mortuary Space in Bronze Age Cyprus. Journal of Mediterranean Archaeology 31: 203-28. [CrossRef]

Webb, Jennifer M. 2019. Socio-spatial Discontinuities in Burial Ritual in Prehistoric Bronze Age Cyprus. In Unlocking Sacred Landscapes: Spatial Analysis of Ritual and Cult in the Mediterranean. Edited by Giorgos Papantoniou, Christine E. Morris and Athanasios K. Vionis. Studies in Mediterranean Archaeology 151. Nicosia: Åström, pp. 171-88.

Webb, Jennifer M., and David Frankel. 2008. Fine Ware Ceramics, Consumption and Commensality: Mechanisms of Horizontal and Vertical Integration in Early Bronze Age Cyprus. In DAIS-The Aegean Feast. Proceedings of the 12th International Aegean Conference/University of Melbourne, Centre for Classics and Archaeology, 25-29 March 2008. Edited by Louise A. Hitchcock, Robert Laffineur and Janice L. Crowley. Aegaeum 29. Liège: Université de Liège, pp. 287-95.

Whitley, James. 2009. The Chimera of Continuity: What Would "Continuity of Cult" Actually Demonstrate? In Archaeologies of Cult: Essays on Ritual and Cult in Crete in Honor of Geraldine C. Gesell. Edited by Anna Lucia D'Agata and Aleydis van de Moortel. Hesperia Supplement 42. Princeton: American School of Classical Studies at Athens, pp. 279-88.

Zukerman, Alexander, Justin Lev-Tov, Liora Kolka-Horwitz, and Aren M. Maeir. 2007. A Bone of Contention? Iron Age IIA Notched Scapulae from Tell eș-Ṣâfī/Gath, Israel. Bulletin of the American Schools of Oriental Research 347: 57-81. [CrossRef] 